\title{
Are Monthly Seasonals Real? A Three Century Perspective
}

\author{
Ben Jacobsen \\ Massey University \\ B.Jacobsen@Massey.ac.nz \\ Cherry Y. Zhang * \\ Massey University \\ Y.Zhang6@Massey.ac.nz
}

\begin{abstract}
Over 300 years of UK stock returns reveal that well-known monthly seasonals are sample specific. For instance, the January effect only emerges around 1830, which coincides with Christmas becoming a public holiday. Most months have had their 50 years of fame, showing the importance of long time series to safeguard against sample selection bias, noise, and data snooping. Only - yet undocumented - monthly July and October effects do persist over three centuries, as does the half yearly Halloween, or Sell-inMay effect. Winter returns - November through April - are consistently higher than (negative) summer returns, indicating predictably negative risk premia. A Sell-in-May trading strategy beats the market more than $80 \%$ of the time over 5 year horizons.
\end{abstract}

Key words: historical data, stock return seasonality, January effect, seasonal anomalies, sell in May, Halloween indicator, tax loss selling

JEL classification codes: G10, G14

${ }^{*}$ Corresponding Author: Cherry Y. Zhang, School of Economics and Finance, Massey University, Private Bag 102 904, NSMC Auckland 0745, New Zealand. Tel: 644140800 ext 9242; E-mail: Y.Zhang6@massey.ac.nz 


\section{Introduction}

Had stock markets been a field of academic study early in the nineteenth century, our predecessors would have wondered about the significantly positive August and December effects and asked themselves why stocks performed so poorly in October. Researchers in the early 1900s pondering a century of stock market returns might have tried to explain the significantly negative July and August effects.

How far are seasonal stock market anomalies real? In their seminal study Lakonishok and Smidt (1988) prescribe long and new data series as the best medicine against data snooping, noise and 'boredom' (selection bias). They confirm many daily anomalies, like the Turn of the Month effect and the Turn of the Week effect, in their extended sample of 90 years of the Dow Jones market index. As they point out at a monthly level, however, they add little new data and even a 90-year sample offers no remedy using monthly frequency data:

“Monthly data provides a good illustration of Black's (1986) point about the difficulty of testing hypotheses with noisy data. It is quite possible that some month is indeed unique, but even with 90 years of data the standard deviation of the mean monthly return is very high (around 0.5 percent). Therefore, unless the unique month outperforms other months by more than 1 percent, it would not be identified as a special month. ”(Lakonishok and Smidt, 1988, p.422)

While new data sets of long time series of stock returns are becoming available, no paper has used these data to verify whether monthly seasonals are real, or are chimeras. This paper fills that gap looking at over 300 years of monthly data on the UK stock market, starting in 1693 . We use these UK data as it is the longest time series available and also provides us with a relatively fresh new data set as they have been less mined than have data from the United States.

Contrary to the Lakonishok and Smidt (1988) results, where their longer sample period confirmed well-known daily effects, our longer series sheds new light on many monthly calendar anomalies. Many months significantly under- or outperform over the full period and in sub periods, but few have done so persistently throughout the ages. Only October and July consistently underperform in our full sample and in all of the 50- and 100-year subsamples. It 
seems Mark Twain was right: October and July are two of the most "peculiarly dangerous months to speculate in stocks in”. July is surprising. While it is the second month in the famous Mark Twain quote no one has, to the best of our knowledge, documented a significant July effect in stock returns before.

No month - including January - significantly outperforms the market persistently in all our 50and 100-year subsamples, although December comes close, only exhibiting below average returns in the first half of the twentieth century. In the first 150 years, instead of being the best performing month, January is worse than average. Before 1830 there is a strong positive December effect, which weakens as the January effect emerges. The January effect cannot have been imported from the US market, as during that period January returns in the US are negative. The only possible explanation seems to be that the actual celebration of Christmas, which started around 1835 in the UK, changed the market dynamics around the turn of the year. Results for the US, where Christmas became a holiday around 1870, show similar evidence for this new explanation on what may be driving the January effect. A capital gains tax in the UK was introduced as late as 1965 and the Tax year has always started in April rather than January. While April did significantly better in the last 50 years, this increase seems to be due to higher returns before, as well as after, 1965. September is often considered to be the worst month, but it both under- and outperforms the market in our 50 year subsamples and is not as bad as October, which in turn shows a persistent underperformance of $0.7 \%$ a month.

November and February are special due to the absence of any significant out- or underperformance through the ages. All other months have had their fifty years of fame at some point during the three centuries, suggesting the importance of studying these long time series.

This long monthly series also allows us to test the persistence of the Sell-in-May effect, or the Halloween effect (Bouman and Jacobsen, 2002), which is the notion that winter returns are substantially higher than summer returns. Studying the Sell-in-May effect is interesting, as it is quickly evolving as one of the strongest anomalies. It challenges traditional economic theory, as it suggests predictably negative excess returns. For instance, Grimbacher, Swinkels and van Vliet (2010) find a US equity premium over the sample 1963-2008 of $7.2 \%$ if there is a 
Halloween effect and a Turn of the Month effect, and a negative risk premium of $-2.8 \%$ in all other cases.

Our focus on the long-term history of UK data is especially interesting, as the United Kingdom is the home of the market wisdom "Sell in May and go away". Popular wisdom suggests that the effect originated from the English upper class spending winter months in London, but spending summer away from the stock market on their estates in the country: An extended version of summer vacations as we know them today. ${ }^{1}$ Thus if the Sell in May anomaly should be significantly present in one country over a long period, one would expect it to be the United Kingdom. ${ }^{2}$

Our evidence shows this to be the case. Winter returns (November through April) are on average a significant $0.56 \%$ higher than (often negative) summer returns. Remarkably, and regardless of all changes that occurred in the world and the United Kingdom over these 300 years, this Sell in May effect persists in all our 100- and 50-year subsamples, and in 24 out of 32 of the 10-year subsamples. Even more remarkable is that summer returns are almost always lower than the risk free rate, suggesting persistent negative risk premia over 300 years. This is not only hard to reconcile with traditional risk return trade off's but this - as argued by Schwert (2003) - also excludes time varying risk premia as a potential explanation for this persistent, predictable pattern. We analyze trading strategies based on this market wisdom and find that investors with a long horizon would have had remarkable odds beating the market using this trading strategy: Over $80 \%$ for investment horizons over 5 years; and over $90 \%$ for horizons over 10 years, with returns on average around three times higher than the market.

\footnotetext{
${ }^{1}$ To give an example: "Historically, the summer fall was caused by farmers selling and sowing their crops and rich investors swanning off to enjoy Ascot, The Derby, Wimbledon, Henley and Cowes. Modern investors jet off to the Med, where they cannot find copies of their pink papers and senior fund managers soak up the sun on Caribbean cruises leaving their nervous second-in-commands in charge” (The Evening Standard, May 26, 1999).

${ }^{2}$ While the first written mention of the market wisdom "Sell in May" occurs in the English Financial Times of Friday 10 of May 1935: "A shrewd North Country correspondent who likes stock exchange flutter now and again writes me that he and his friends are at present drawing in their horns on the strength of the old adage "Sell in May and go away."' The suggestion is that at the time it is already an old market saying. This is confirmed by a more recent article in the Telegraph. (http://www.telegraph.co.uk/finance/2914779/Should-you-sell-in-May-and-buyanother-day.html) In the article "Should you "Sell in May and buy another day?" the journalist "George Trefgarne refers to Douglas Eaton, who in that year was 88 and was still working as a broker at Walker, Cripps, Weddle \& Beck. "He says he remembers old brokers using the adage when he first worked on the floor of the exchange as a Blue Button, or messenger, in 1934. "It was always sell in May," he says. "I think it came about because that is when so many of those who originate the business in the market start to take their holidays, go to Lord's, [Lord's cricket ground] and all that sort of thing.”
} 
Research into calendar anomalies is one of the oldest strands in the finance literature, starting with Wachtel's study in 1942 on the January effect, and followed by many other, now classic, studies including Rozeff and Kinney (1976), French (1980), Gibbons and Hess (1981), Lakonishok and Levi (1982), Roll (1983), Keim (1983), Reinganum (1983), and Ariel (1987). Ever since 1942, old and new calendar anomalies (like the other January effect (Cooper, McConnell, and Ovtchinnikov, 2006) and seasonal effects in the cross-section of stock returns (Heston and Sadka, 2007)) keep practitioners and academics intrigued. Grimbacher, Swinkels and van Vliet (2010) try to disentangle the different calendar anomalies. Ogden (2003) relates equity return patterns to the seasonality of macroeconomic variables and a recent paper by Ogden and Fitzpatrick (2010) shows that many other anomalies, like the failure-risk anomaly, earnings momentum, and the book-to-market anomaly, may also be seasonal. Many papers now assume there are seasonal anomalies, like the January effect, and try to explain them. We feel that our paper contributes to the literature, as it takes a step back and asks the question - using these new historical data - of whether or not these monthly seasonal anomalies exist and, if so, when and why they emerge. For instance, the persistence of the Sell-in-May effect suggests it is caused by a fundamental factor, which has not changed over three hundred years. Moreover, if a change occurs in the seasonal effect, this long time series allows us to consider whether fundamental changes, like the introduction of a Christmas holiday, may cause a shift in market dynamics. Thus, understanding whether, and if so which, calendar anomalies persist helps our understanding of the working of financial markets and the behavior of investors. Our analysis of these longer new series puts both the January effect and the Halloween effect into a new perspective. Moreover, our evidence that the Sell-in-May effect is persistent over time and not a fluke is important, as it suggest that during half of the year the fundamental relation between risk and expected return is systematically violated.

\section{Data}

UK stock return index

We obtain a 317-year index of monthly UK stock prices compiled by Global Financial Data from several different sources. Starting from 1693, the index basically covers the entire trading history of the UK equity market. Table 1 summarises the sources. 


\section{Please insert Table 1 around here}

The index consists of stocks of the East India Company, the Bank of England, and the South Sea Company for the first 110 years. These stocks were the largest public firms and their prices were the most regularly followed by the media at the time (Mirowski, 1981). During the eighteenth century, the trading volume was relatively thin, although the estimated number of stocks was around 150 by the end of seventeenth century, and had grown to around 340 during the time of the South Sea Bubble. Most of these companies disappeared during the Bubble (Michie, 1999). Mirowski (1981) examines surviving financial reports of some investing companies, indicating that their major investments were unanimously in these particular companies. In addition, he constructs an annual index consisting of up to 8 stocks $^{3}$ for the eighteenth century and shows that, except for the bubble period in 1720, all of the shares are highly correlated, which implies that the 3-stock index is a sound proxy for the general movement of the market.

For the first half of nineteenth century, the index adopts Rostow's total index (1811-1850) and Hayek’s index (1851-1867), which are sourced from Gayer, Rostow and Schwartz (1975). Both indices are broad based and favour large and frequently traded companies. The Rostow's total index represents one-third of the companies officially listed in the market. For the second half of the nineteenth century, the index uses the London and Cambridge Economic Service index constructed by Smith and G.F. Horne, which is the most widely studied index for the pre-World War I period. The Banker's Magazine index applies for the period from 1907 to 1933. It is the broadest index of London shares for the period. The stock market ceased trading for 5 months from August 1914 to December 1914. We treat the data for this period as missing. The index consists of the Actuaries General Index from 1933 to 1962, and the Financial Times-Actuaries All-Share index, which covers about 98\%-99\% of the capital value of all UK companies from April 1962 onwards.

Most of these sub-indices are frequently used in other empirical studies; for example, Shiller (1988), Goetzmann (1993), and Goetzmann and Jorion (1995). The series does not include

\footnotetext{
${ }^{3}$ Among the eight stocks, only the three companies included in our index have a continuous record for the whole of the eighteenth century.
} 
dividends. Global Financial Data also has a total return index over the same period, however, this index is based mostly on the Bank of England stock until 1922.

\section{Interest rate}

We use the UK 3-month T-bills rate as our proxy for the risk free rate, however, this data series only starts from 1900. Prior to 1900, we choose the Bank of England base lending rate, beginning from August 1694, since its correlation with the UK T-bills rate is as high as 0.99. We set the interest rate to zero for the one year prior to August 1694 when there are no data available.

\section{Monthly Seasonality}

Are stock returns in the different months significantly different from each other? To study the potential effects of sample sizes on monthly stock returns, as discussed in Lakonishok and Smidt (1988), we consider the full sample and also divide it into three (roughly) one-hundred-year subperiods and six sub-periods of around fifty years. This allows us to examine the monthly stock return seasonality with relatively large sample sizes, while still being able to detect any trends and persistent patterns over time. Table 2 reports the results for the general seasonality tests, as well as the mean returns and standard deviations for each calendar month and entire year over the various sample periods and some basic characteristics for the interest rates used.

Please insert Table 2 around here.

The latest 50-year subsample enables us to confirm the findings of earlier studies, ${ }^{4}$ and the other two and a half centuries data can be safely treated as fresh data for out of sample tests over a longer time period, as they have not been studied before in relation to seasonal anomalies.

\footnotetext{
${ }^{4}$ Seasonality studies for the US market include earlier periods (i.e. sample period in Wachtel (1942) starts from 1927, Rozeff and Kinney (1976) from 1904, Schultz (1985) from 1900, and Jones et al. (1987) from 1871). Sample periods in seasonality studies of UK market focus on the latest 50-year sub-period of our sample. For example, Gultekin and Gultekin (1983) examine UK data from 1959 to 1979, Corhay, Hawawini and Michel (1987) consider the period 1969-1983, and Reinganum and Shapiro (1987) use the period 1955-1980.
} 
Overall, the average monthly return over the entire sample is only $0.12 \%$ ( $1.44 \%$ per year), which is relatively low, but this is due to the negative average returns during the first 150 years. Negative capital gains in the long run may seem surprising nowadays, however, during the eighteenth and nineteenth centuries dividends were relatively more important. We see relatively high dividend payments (around 5\% annually) in the first two centuries of our sample: The series including dividends (not reported in the table) has monthly returns of $0.53 \%$ and $0.40 \%$ in the first two centuries, respectively.

We observe an increasing trend in average price returns over time, with the latest 50 years showing the highest average return. While the standard deviations of different sample periods do not have a clear pattern, the market in the nineteenth century seems to be less volatile than it does in the eighteenth and twentieth centuries.

The last two columns report the results of the calendar month seasonality tests. We use both parametric and non-parametric tests. The latter is the Kruskal and Wallis rank-based test of equality. The null hypothesis is that all of the calendar months have the same continuous distribution and that the test statistic is approximately distributed as a $\chi^{2}$ with 11 degrees of freedom. The alternative hypothesis is that at least one month has a different distribution. The parametric test examines the joint significance of parameters $\alpha_{2}$ to $\alpha_{12}$ from the following regression equation:

$R_{t}=\alpha_{1}+\alpha_{2} D_{2 t}+\alpha_{3} D_{3 t}+\cdots+\alpha_{12} D_{12 t}+\varepsilon_{t}$

where $R_{t}$ is the monthly continuously compounded index returns, $D_{2 t} \ldots D_{12 t}$ denote dummy variables for February to December. The constant parameter $\alpha_{1}$ is the average return for January, and the coefficient estimates $\alpha_{2}$ to $\alpha_{12}$ represent the differences between January returns and the returns in other months. If returns for each month of the year are the same, the parameters $\alpha_{2}$ to $\alpha_{12}$ should be jointly insignificant. Both tests reveal strong calendar month seasonality over all of our examined sample periods. 
While our tests statistics indicate significant differences between months, these tests do not clarify which month contributes to this seasonality and whether it is the same month in different samples. Based on the literature, we expect to see higher returns in January and April. The January effect is the most well-known monthly return seasonal first documented in Wachtel (1942), and formally tested and made popular among academia by Rozeff and Kinney (1976) using 70 years of US data from 1904 to 1974. Follow up studies attribute the January effect to the tax loss selling hypothesis ${ }^{5}$ (see Keim (1983), Reinganum (1983), Roll (1983), and Schultz (1985) for US evidence; Corhay, Hawawini and Michel (1987) and Gultekin and Gultekin (1983) for international evidence). While studies outside the US show mixed results (see Brown et al. (1982) for the Australian market, and Berge et al. (1984) and Tinic et al. (1987) for Canadian evidence), UK evidence is supportive of the tax-loss selling hypothesis. In particular, with a tax year ending on 5 April, studies find that UK stock returns in January ${ }^{6}$ and April are significantly higher than returns in other months. For instance, using a 20 year sample from 1959 to 1979, Gultekin and Gultekin (1983) observe that April returns are much larger than over the remainder of the year. Reinganum and Shapiro (1987), using monthly share price data from 1955 to 1980, find UK stock returns exhibit both a January and an April seasonal effect after the introduction of capital gain taxes in April 1965, while no seasonality is detected prior to that date. In addition to the higher January and April returns, a later study by Clare, Psaradakis, and Thomas (1995) reports high December returns and low September returns in the UK stock market over the sample period of 1955 to 1990. Our results confirm these findings. For the subsample period 1951 to 2009, April, December, and January have the highest returns, while the average September return is the lowest during the period. The interesting question is whether we will find similar results in earlier subperiods.

Our evidence in Table 2 suggests that these patterns do not persist over time. January returns are negative and lower than for the other months in the first 100 years, with the best month over the

\footnotetext{
${ }^{5}$ The tax loss selling hypothesis is an explanation for the January effect, first proposed by Wachtel (1942). He states that downward pressure on stock prices might be induced at year end by investors selling the losing stocks with the intention to realize capital losses against their taxable incomes. The abnormally high January return is the effect from the stock price rebounding to its equilibrium level when the selling pressure stops at the beginning of the year. ${ }^{6}$ A January effect might be caused by international stock market integration; see Gultekin and Gultekin (1983) for evidence of the January effect in capital markets around the world. In addition, Reinganum and Shapiro (1987) suggest that the January effect in the UK stock market is driven by corporations that have a tax year ending at the end of December.
} 
300 years being December rather than January. The overall performance of October seems worse than that for September ( $-0.51 \%$ versus $-0.49 \%$ return per month), but the average October return is higher than September in the most recent 50 years. In Table 3 we test the statistical significance of the individual months in more detail, using the standard random walk regression with a dummy variable:

$R_{t}=\alpha+\beta_{m} D_{m t}+\varepsilon_{t}$

where $R_{t}$ is the continuously compounded monthly index return, $D_{m t}$ is the dummy variable for a particular month, $\alpha$ is the constant, and $\varepsilon_{t}$ is the error term. $\beta_{m}$ shows the magnitude of the difference between the mean return of the month of interest and the mean return during the rest of the year.

Please insert Table 3 around here.

Table 3 contains our coefficient estimates and t-statistics based on Newey-West standard errors for each calendar month. As before, we consider the full sample results and the 100 and 50 year subsamples.

Over the entire sample period, the December, January, April, and August returns are significantly higher than the returns for the rest of the year. Despite this, however, none of these months outperforms the market persistently. December comes close, with negative coefficient estimates only in the sub-period 1901-1950. Even the well-known January effect appears only in the second half of our sample. Intriguingly, on average, the January returns are significantly lower rather than higher during the eighteenth century. Before 1850, a strong positive December effect dominates the market, which disappears as the January effect emerges in the nineteenth century.

Please insert Figure 1 around here. 
Figure 1 shows this shift in January returns more clearly. We plot a 10-year moving average of the annual difference between January returns and the average returns of the other calendar months. January returns are rarely higher than the average months until the 1820s to 1830 s. (Note that the extremely high January returns exhibited in the 1820s are partially caused by the Panic of $1825^{7}$ leading to an upward shift and, subsequently, to a strong downward shift in the 10-year moving average.) Only around this time do January returns become higher than those of other months and these higher returns continue to the end of the twentieth century. The higher January returns start from the mid-1830s if we exclude the extreme price behaviour in 1825. It is, however, not clear what causes this January effect, as a tax loss selling explanation does not seem feasible. In particular, the UK capital gains tax was not imposed until 1965 with a tax year end of April, and income tax was first introduced in 1799, but repealed in 1816 and not reintroduced until 1842, however, neither of these periods coincide with the emergence of the January effect in the 1830s. Thus, tax loss selling by individual investors with an April tax year end, or corporations and traders with a December tax year end, cannot explain the effect. In addition, income tax was not prevalent in other countries during the nineteenth century. For example, the US introduced the War Revenue Act in 1917, therefore the emerging January effect cannot have been carried over from the US. Tax-loss selling by foreign traders is also unable to explain the emergence of the January effect in the 1830s. An alternative explanation would be that the January effect is imported from the US market for a different reason, however, January returns in the US are significantly below average in this period, as shown in Figure 2. In this figure we plot a 10-year moving average of the difference between January returns and the average returns in the 11 other months for the US.

\section{Please insert Figure 2.around here}

\footnotetext{
${ }^{7}$ During the period, our index shows that the price level started to rise dramatically, by more than $20 \%$ per month, from November 1824, and had the largest increase of 54\% in January 1825. Price levels remained high for 3 months and then sharply dropped back to the original level within a year. This price behavior is consistent with the description in Glasner (1997, p.511), “... a speculative fever which seems to have begun in late 1824. They included a widespread feeling of optimism at the time, a general shortage of investment vehicles resulting from the decrease in the interests on bonds, an excess demand for several commodities, and the opening up of investment opportunities in South America...At the beginning of 1824, there were 154 joint stock companies with capital of $£ 48$ million. An additional 624 such companies were either started or proposed during the next two years, 127 of which survived the crisis and were still in operation in 1927. The crash in the real sector followed that of the financial sector, with the bottom being reached in 1826.”
} 
If we combine this with the results for December from Table 3 we see that not only a January effect emerges, but also that December stops significantly outperforming after 1850. In fact, December almost always outperforms January until the mid-1830s, when the situation is reversed and January returns start to dominate December returns. There seems to be a transition period from 1830 to 1850, when the January effect tends to become stronger, while the December effect tends to weaken. We find only one significant change during this time which could be responsible for the shift: The celebration of Christmas. Wikipedia, for instance, reports that the attention on Christmas increased dramatically around this time and the United Kingdom started officially celebrating Christmas in 1835 or $1837 .{ }^{8}$ So it could well be that, for whatever reason, the introduction of this official holiday caused a January effect to emerge. If so, we would expect a similar phenomenon in the United States when Christmas became an official holiday around 1870. Christmas was declared a legal holiday in 1870 by President Ulysses S. Grant, but the website http://www.timeanddate.com/holidays/us/christmas-day suggests celebrations started earlier: “...from about 1840, celebrating Christmas became more widespread. December 25 was declared a federal holiday in the United States in 1870. Since then Christmas Day has become steadily more important”.

We test whether the introduction of an official Christmas holiday might have led to the emerging of the January effect using the following regression:

$R_{t}=\alpha+\beta_{b} \operatorname{Jan}_{t}\left(1-\right.$ Christmas $\left._{t}\right)+\beta_{a}$ Jan $_{t}$ Christmas $_{t}+\varepsilon_{t}$

where $R_{t}$ is the continuously compounded index returns, Jan $n_{t}$ is the January dummy, Christmas $_{t}$ is a dummy variable that equals one for the period after the introduction of the

\footnotetext{
${ }^{8}$ Christmas becomes a national holiday in 1835 according to the website http://www.johnowensmith.co.uk/histdate/, but other sources (http://www.historic-uk.com/HistoryUK/England-History/VictorianChristmas.htm) suggest that the Christmas holiday is introduced later, in 1837: "Before Victoria's reign started in 1837 nobody in Britain had heard of Santa Claus or Christmas Crackers. No Christmas cards were sent and most people did not have holidays from work. The wealth and technologies generated by the industrial revolution of the Victorian era changed the face of Christmas forever...the wealth generated by the new factories and industries of the Victorian age allowed middle class families in England and Wales to take time off work and celebrate over two days, Christmas Day and Boxing Day. Boxing Day, December 26th, earned its name as the day servants and working people opened the boxes in which they had collected gifts of money from the "rich folk". Those new fangled inventions, the railways allowed the country folk who had moved into the towns and cities in search of work to return home for a family Christmas."
} 
Christmas holiday and zero otherwise, where we use 1870 as a breakpoint for the US and 1837 for the United Kingdom. The parameter estimate $\beta_{b}$ represents the January effect before the breakpoint year and $\beta_{a}$ shows the January effect after the breakpoint year. We examine the effect for the whole sample period, as well as 50 years (100 years) before, and after, the breakpoints. Table 4 presents the estimation results for both the US and the UK.

\section{Please insert Table 4 around here.}

We find the higher than average January returns are only present in the sample period after Christmas becoming national holiday. Prior to the breakpoint year, the coefficient estimates for the January effect are not significantly higher than the market, with January returns lower than average for all of the US sample periods, and for the whole sample period of the UK market. After the Christmas breakpoint, the January effect emerges, as returns are significantly higher than for the rest of the year. The last two columns of Table 4 examine the difference in the January effect before and after the breakpoint. The results indicate a significant change: January returns before breakpoints are statistically significantly lower than January returns after the breakpoint for both countries and for all of the sample periods, with the exception of the UK over the period of 1787-1887.

This finding suggests that the official celebration of Christmas may be an important factor behind the January effect. It might be that investors delay planned purchases until January, or that Christmas introduced a time for reflection, or that the lack of trading in December drives prices up in the beginning of the New Year when liquidity returns. A Christmas explanation would also be consistent with a January effect in countries even where the end of the tax year falls in a different month, as in the UK.

In the UK a capital gains tax was introduced on April 6, 1965. Results of, for instance, Reinganum and Shapiro (1987) suggest that this leads to the introduction of higher April returns from that point on. They find no seasonality in monthly UK returns in the 10 years prior to the introduction of capital gains tax. Having the benefit of a longer sample, we can revisit their evidence. In Figure 3 we plot April returns, April returns minus the average returns of the other 
11 months, and a 10-year moving average of April returns minus the average returns of the other months. All plots refer to the 1900-2009 period, as this is when the April effect becomes significantly positive.

\section{Please insert Figure 3 around here.}

Positive April returns occur frequently, however, it is not definite that the outperformance occurs only in the period after the imposition of capital gains tax in 1965. In fact, the smoothed graph using a 10-year moving average shown in the third plot reveals that the rising trend starts from the 1940s onwards. This suggests that it may not necessarily be the capital gains tax that causes these higher April returns.

Table 2 shows that the average returns for October, September, and July are frequently negative. Table 3 reveals that the relatively worst months are October and July, which persistently and significantly underperform the other calendar months over the whole sample period. They also underperform in all sub-periods. Although the results are not statistically significant for all subsamples, the coefficient estimates are unanimously negative. The average return for October over the whole sample period is $0.68 \%$ lower than the other months' averages. For July this is $0.46 \%$. This result appears to be consistent with Mark Twain's saying about the stock market, recorded in his novel Pudd'nhead Wilson (first published in 1894), which states: “October. This is one of the peculiarly dangerous months to speculate in stocks. The others are July, January, September, April, November, May, March, June, December, August, and February”. Although the statistical significance shows a weakening trend after the 1850s, the average monthly returns of both months still remain lower than the mean returns for the other months. This result also holds in the latest 50-year sample period.

Our results confirm the low September returns reported by Clare, Psaradakis and Thomas (1995) for the period of 1955-1990. With the benefit of a longer sample period, however, we are able to show that the pattern is not persistent and that the September mean returns are actually higher than the returns during the other months for three out of the six fifty-year sub-periods, although the difference is not statistically significant. 


\section{The Halloween Effect}

While most monthly seasonals seem time dependent, the Halloween effect is remarkably robust across subsamples. The Halloween, or Sell-in-May, effect is a phenomenon based on the old UK market wisdom "Sell-in-May and go away" (and the Halloween indicator in the US), which indicates that winter returns (November through April) tend to be significantly higher than summer returns (May through October). Bouman and Jacobsen (2002) find this effect presents in 36 of the 37 countries in their study.

In Table 5 we compare summer and winter returns for our full sample and subsamples.

Please insert Table 5 around here.

Average winter returns are positive, and higher than summer returns, for all sample periods. The percentage of positive returns is always greater than $50 \%$, indicating that this result is not due to outliers. In contrast, with the exception of the sub-period 1851-1900, summer returns are always negative, implying persistent negative risk premia over summer through the ages. ${ }^{9}$ The calendar month returns shown in Table 2 also reveal this pattern: Mean returns during summer months are frequently negative and lower than the mean returns in the winter months. The monthly dummy coefficients reported in Table 3 confirm that returns in summer months tend to be below average and in winter above average.

Please insert Figure 4 around here.

We test the persistency of the Sell-in-May effect in Figure 4, using shorter intervals of ten years. The upper plot compares historical winter returns and summer returns over ten-year horizons (in descending order based on summer returns). For the thirty-two ten-year average returns, we only observe nine positive summer returns compared to twenty-three positive winter returns. In the lower plot we arrange the differences between winter returns and summer returns in ascending order. Summer returns exceed winter returns in only eight of the thirty-two periods, and the

\footnotetext{
${ }^{9}$ We also find this for the series that includes dividends: Monthly average total returns minus the monthly interest rate equals $-0.03 \%$.
} 
magnitude of the difference tends to be relatively small. The best summer return outperforms winter return by only $0.65 \%$ in the period $1791-1800$. Winter returns are often substantially higher, with the highest difference between winter returns and summer returns equal to $2.85 \%$ in the period 1971-1980.

The last two columns of Table 5 report the regression results of monthly market index returns on a constant, and a Halloween dummy that equals one if the month falls in the period of November through April and zero otherwise. The coefficients for the Halloween dummy are consistently positive. The effect is stronger in recent periods and is particularly significant over the latest fifty years.

Powell, Shi, Smith and Whaley (2009) question the accuracy of the statistical inference drawn from standard OLS estimation with Newey and West (1987) standard errors when the regressor is persistent, or has a highly autocorrelated dummy variable and the dependent variable is positively autocorrelated. They suggest that this may affect the statistical significance of the Halloween effect. This argument has been echoed in Ferson (2007), however, it is easy to show that this is not a concern here. We find that statistical significance is not affected if we examine the statistical significance of the Halloween effect using 6-month summer and winter returns. By construction, this half-yearly Halloween dummy is negatively autocorrelated. Powell Shi, Smith, and Whaley (2009) show the confidence intervals actually narrow relative to conventional confidence intervals when the regressor's autocorrelation is negative, causing standard tstatistics to under-reject rather than over-reject the null hypothesis of no effect. Thus, as a robustness check, it seems safe to test the Halloween effect using standard t-statistics adjusted with Newey and West (1987) standard errors from semi-annual return data. Table 6 presents the coefficient estimates and t-statistics.

Please insert Table 6 around here.

The results drawn from semi-annual data do not change our earlier conclusion based on monthly returns. If anything, these results show an even stronger Halloween effect. The periods with significant Halloween effect in our earlier tests remain statistically significant with t-values based on semi-annual data. The first hundred years (1693-1800) period was not statistically 
significant using the monthly data, but now becomes significant at the $10 \%$ level. As a final test, we use a simple equality in means test. In this case, we also reject the hypothesis that summer and winter returns are different, with almost the same, highly significant, t-value (4.20).

\section{Persistency of negative summer risk premia}

Another intriguing pattern implied by the Sell-in-May effect is that the frequently observed negative summer returns over time indicates persistent negative summer risk premia. We now examine in more detail whether summer returns are consistently lower than the risk free rate. The summer risk premia are calculated by subtracting the interest rate from summer returns. Over the whole sample period, the average risk premium is $-0.53 \%$ and, out of 317 years, we observe 201 years (63\%) of negative risk premia during summer. In Figure 5 we plot smoothed summer risk premia using a 10-year moving average every year for over 300 years.

Please insert Figure 5 around here.

The summer risk prima is only occasionally positive during the period of the 1930s to 1950s, and it is persistently negative over the remainder of the 280 years. This persistent pattern of negative summer returns challenges the traditional risk expected return relation, as it suggests predictably negative summer excess returns.

\section{Performance of trading strategies based on the Halloween indicator}

Bouman and Jacobsen (2002) develop a simple trading strategy based on the Halloween indicator and the Sell-in-May effect, which invests in a market portfolio at the end of October for six months and sells the portfolio at the beginning of May, using the proceeds to purchase risk free short term Treasury bonds and hold these from the beginning of May to the end of October. They find the Halloween strategy outperforms a buy and hold strategy even after taking transaction costs into account. We examine the performance of this Halloween strategy over three-hundred years. Table 7 presents the performance of the Halloween strategy relative to the buy and hold strategy over different subsample periods. 


\section{Please insert Table 7 around here.}

The average annual returns reported in the second and the fifth columns reveal that the Halloween strategy consistently beats a buy and hold strategy over the whole sample period, and in all hundred-year and fifty-year subsamples. It only underperforms the buy and hold strategy in one out of ten of the thirty-year subsamples (1941-1970). The magnitude with which the Halloween strategy outperforms the market is also considerable. For example, the returns of the Halloween strategy are almost three times as large as the market returns over the whole sample. In addition, the risk of the Halloween strategy measured by the standard deviation of the annual returns is, in general, smaller than for the buy and hold strategy. This is evident in all of the sample periods we examine. Sharpe ratios for each strategy are shown in the fourth and the seventh columns. Sharpe ratios for the Halloween strategy are unanimously higher than those for the buy and hold strategy. Table 7 also reveals the persistence of the outperformance of the Halloween strategy within each of the subsample periods by indicating the percentage of years that the Halloween strategy beats the buy and hold strategy. Over the whole sample period, the Halloween strategy outperforms the buy and hold strategy in 63.09\% (200/317) of the years. All of the hundred-year and fifty-year subsample periods have a winning rate higher than 50\%. Only one of the thirty-year subsamples has a winning rate below 50\% (1941-1970, 43.33\%).

Most investors will, however, have shorter investment horizons than the subsample periods used above. Using this large sample of observations allows us a realistic indication of the strategy over different short term investment horizons. Table 8 contains our results. It compares the descriptive statistics of both strategies over incremental investment horizons, ranging from one year to twenty years. Returns, standard deviations, and maximum and minimum values are annualized to make the statistics of different holding periods comparable. The upper panel shows the results calculated from overlapping samples and the lower panel contains the results for nonoverlapping samples.

Please insert Table 8 around here.

The two sampling methods produce similar results. For every horizon, average returns are significantly higher for the Halloween strategy: Roughly three times as high as for the buy and 
hold strategy. For shorter horizons the standard deviation is lower for the Halloween strategy than for the buy and hold strategy. For longer investment horizons, however, the standard deviation is higher. This seems to be the result of positive skewness, indicating that we observe more extreme positive returns for the Halloween strategy than for the buy and hold strategy. The frequency distribution plots in Figure 6 confirm this. The graphs reveal that the returns of the Halloween strategy produce less extreme negative values, and more extreme positive values, than the buy and hold strategy.

Please insert figure 6 around here.

This is also confirmed if we consider the maximum and minimum returns of the strategies shown in Table 8. Except for the one-year holding horizon, the maximum returns for the Halloween strategy of different investment horizons are always higher than for the buy and hold strategy, whereas the minimum returns are always lower for the buy and hold strategy. The last column of Table 8 presents the percentage of times that the Halloween strategy outperforms the buy and hold strategy. The results calculated from the overlapping sample indicate that, for example, when investing in the Halloween strategy for any two-year horizon over the 317 years, an investor would have had a $70.57 \%$ chance to beat the market. The percentage of winnings computed from the non-overlapping sample, shown in the lower panel, yields similar results. Once we expand the holding period for the Halloween trading strategy, the possibility of beating the market increases dramatically. If an investor uses a Halloween strategy with an investment horizon of five years, the chances of beating the market rises to $82.11 \%$. As the horizon expands to ten years, this probability increases to a striking $91.56 \%$.

As a last indication of the persistency of the Halloween strategy over time, In Figure 7 we compare the cumulative annual return over the three centuries. The buy and hold strategy hardly shows an increase in wealth until 1950 (Note that this is a price index and the series do not include dividends). The cumulative wealth of the Halloween strategy increases gradually over time and at an even faster rate since 1950.

Please insert figure 7 around here. 


\section{Conclusion}

This study investigates monthly return seasonality using 300 years of UK stock market data. We show that many calendar months significantly outperform, or underperform, the market in our sample, but that few have done so persistently over the 300 years. This result confirms the potential problems caused by data snooping, noise, and selection bias, and highlights the importance of studying long time series. In particular, we find that January returns used to be lower, rather than higher, than the other months over the first 150 years. A strong positive December effect dominates the market prior to the 1850s, which disappears as the January effect emerges. The only explanation we find for this is that at this time in UK history celebrating Christmas became more popular. Results for the US confirm the link between the introduction of a Christmas holiday and the beginning of a January effect. We find no evidence that the significance of the positive April effect in the last century is caused by capital gains tax being introduced in the UK in 1965, as the strengthening of the April effect seems to start from the 1940s. The only persistent pattern we detect for the calendar months over the three-hundred year period is the underperformance of the market in October and July.

In contrast to most calendar months, the Halloween effect is robust over different subsample periods. We show persistently negative summer risk premia over 300 years. Trading rules based on the Halloween effect consistently beat the market. For instance, a Halloween (or Sell-in-May) trading strategy beats the market more than $80 \%$ of the time over 5 -year horizons and more than $90 \%$ of the time for 10 -year horizons. 


\section{References}

Ariel, Robert A., 1987, A monthly effect in stock returns, Journal of Financial Economics 18, 161-174.

Berge, Angel, John J. McConnell, and Gary G. Schlarbaum, 1984, The turn-of-the-year in Canada, Journal of Finance 39, 185-192.

Bouman, Sven, and Ben Jacobsen, 2002, The Halloween indicator, "Sell in May and go away": Another puzzle, American Economic Review 92, 1618-1635.

Brown, Philip, Donald Keim, Allan Kleidon, and T. A. Marsh, 1982, Stock return seasonalities and the tax-loss selling hypothesis: Analysis of the arguments and Australian evidence, Journal of Financial Economics 12, 105-127.

Clare, Andrew D., Zacharias Psaradakis, and Stephen H. Thomas, 1995, An analysis of seasonality in the UK Equity market, Economic Journal 105, 398-409.

Cooper, Michael J., John J. McConnell, and Alexei V. Ovtchinnikov, 2006, The other January effect, Journal of Financial Economics 82, 315-341.

Corhay, Albert, Gabriel Hawawini, and Pierre Michel, 1987, Seasonality in the risk-return relationship: Some international evidence, Journal of Finance 42.

Ferson, W. Market Efficiency and Forecasting, 2007, in Forecasting Expected Returns in the Financial Markets, Stephen Satchell (ed.), Academic Press/Elsevier, pp. 1-16.

French, Kenneth R., 1980, Stock returns and the weekend effect, Journal of Financial Economics 8, 55-69.

Gayer, Arthur D., W. W. Rostow, and Anna Jacobson Schwartz, 1975. The growth and fluctuation of the British economy 1790-1850, an historical, statistical, and theoretical study of Britain's economic development, The Harvester Press Limited.

Gibbons, Michael R. and Patrick Hess, 1981, Day of the week effects and asset returns, Journal of Business 54, 579-596.

Glasner, David, 1997, Business Cycles and Depressions - An Encyclopedia, New York \& London: Garland Publishing Inc.

Goetzmann, William N., 1993, Patterns in three centuries of stock market prices, Journal of Business 66, 249-270.

Goetzmann, William N. and Philippe Jorion, 1995, A longer look at dividend yields, Journal of Business 68, 483-508.

Grimbacher, Stefan Benjamin, Laurens A. P. Swinkels, and Pim van Vliet, 2010, An anatomy of calendar effects, Working Paper Available at SSRN: http://ssrn.com/abstract=1593770.

Gultekin, Mustafa N. and N. Bulent Gultekin, 1983, Stock market seasonality international evidence, Journal of Financial Economics 12, 469-481.

Haugen, R. and Josef Lakonishok, 1988. The incredible January effect: The stock market's unsolved mystery, Homewood, Illinois: Dow-Jones-Irwin. 
Heston, Steven L. and Ronnie Sadka, 2007, Seasonality in the cross-section of stock returns, Journal of Financial Economics 87, 418-445.

Historic UK.com, A Victorian Christmas, http://www.historic-uk.com/HistoryUK/EnglandHistory/VictorianChristmas.htm, access date 10/09/2010.

Jacobsen, Ben, Abdullah Mamun, and Nuttawat Visaltanachoti, 2005, Seasonal, size and value anomalies, Working Paper, Available at SSRN: http://ssrn.com/abstract=784186.

Jacobsen, Ben and Wessel Marquering, 2008, Is it the wealther?, Journal of Banking \& Finance 32, 526-540.

Jones, Charles P., Douglas K. Pearce, and Jack W. Wilson, 1987, Can tax-loss selling explain the January effect? A note, Journal of Finance 42, 453-461.

Keim, Donald, 1983, Size-related anomalies and stock return seasonality: Further empirical evidence, Journal of Financial Economics 12, 13-32.

Lakonishok, Josef and Levi, Mauric D. 1982. Weekend effects on stock returns, Journal of Finance 37, 883-889.

Lakonishok, Josef and Seymour Smidt, 1988, Are seasonal anomalies real? A ninety-year perspective, Review of Financial Studies 1, 403-425.

Michie, Ranald C., 1999. The London stock exchange - a history, New York: Oxford University Press.

Mirowski, Philip, 1981, The rise (and retreat) of a market: English joint stock shares in the eighteenth century, Journal of Economic History 41, 559-577.

Newey, W. K. and K. D. West, 1987, A simple, positive semi-definite, heteroskedasticity and autocorrelation consistent covariance matrix, Econometrica 55, 7003-7708.

Ogden, Joseph P., 2003, The calendar structure of risk and expected returns on stocks and bonds, Journal of Financial Economics 70, 29-67.

Ogden, Joseph P. and Julie Fitzpatrick, 2010, Do five asset pricing anomalies share a common mispricing factors? Multifaceted empirical analyses of failure risk proxies, external financing, and stock returns, Working Paper Available at SSRN: http://ssrn.com/abstract=1566223.

Powell, John G., Jing Shi, Tom Smith, and Robert E. Whaley, 2009, Political regimes, business cycles, seasonalities, and returns, Journal of Banking \& Finance 33, 1112-1128.

Reinganum, Marc R., 1983, The anomalous stock market behavior of small firms in January empirical tests for tax-loss selling effects, Journal of Financial Economics 12, 89-104.

Reinganum, Marc R. and Alan C. Shapiro, 1987, Taxes and stock return seasonality: Evidence from the London stock exchange, Journal of Business 60, 281-295.

Roll, Richard, 1983, Vas ist das? The turn-of-the-year effect and the return premia of small firms, Journal of Portfolio Management Winter, 18-28.

Rozeff, Michael S. and William R. Kinney, 1976, Capital market seasonality: The case of stock returns, Journal of Financial Economics 3, 379-402.

Schultz, Paul, 1985, Personal income taxes and the January effect: Small firm stock returns before the war revenue act of 1917: A note, Journal of Finance 40, 333-343. 
Schwert, G. William, 2002, Anomalies and market efficiency, in Constantinides, Harris, and Stulz (eds.) Handbook of economics and finance.

Shiller, Robert J., 1988, Comovements in stock prices and comovements in dividends, Journal of Finance 44, 719-729.

Smith, John Owen, Useful dates in British history for the local historian or genealogist http://www.johnowensmith.co.uk/histdate/, access date 10/9/2010.

Sullivan, Ryan, Allan Timmermann, and Halbert White, 2001, Dangers of data mining: The case of calendar effects in stock returns, Journal of Econometrics 105, 249-286.

Timeanddate.com, Christmas day in United States, http://www.timeanddate.com/holidays/us/christmas-day, access date 10/9/2010.

Tinic, Seha M., Barone Giovanni Adeshi, and Richard R. West, 1987, Seasonality in Canadian stock prices: A test of the "Tax-loss-selling" Hypothesis, Journal of Financial and Quantitative Analysis 22, 51-63.

Trefgarne, George, 2005, Sould you sell in may and buy another day? http://www.telegraph.co.uk/finance/2914779/Should-you-sell-in-May-and-buy-anotherday.html, access date 10/09/2010

Wachtel, Sidney B., 1942, Certain observations on seasonal movements in stock prices, Journal of Business 15, 184-193. 
Table 1. Sources and descriptive statistics of sub-indices

\begin{tabular}{|c|c|c|c|c|c|c|}
\hline Dates & Source & No. Of Stocks & Companies/Types & $\begin{array}{l}\text { Weighting } \\
\text { Method }\end{array}$ & $\begin{array}{l}\text { Mean } \\
(\%)\end{array}$ & $\begin{array}{l}\text { Std. Dev. } \\
(\%)\end{array}$ \\
\hline 1693 & & 1 & East Indies Stock & -- & -0.32 & 5.94 \\
\hline $1694-08 / 1711$ & $\begin{array}{l}\text { Thorold Roger, A } \\
\text { history of prices in } \\
\text { England (1693-1697); } \\
\text { Larry Neal, The rise of } \\
\text { financial capitalism }\end{array}$ & 2 & Bank of England \& East Indies Stock & Equal Weighted & & \\
\hline 09/1711-01/1811 & (1698-Jan 1811) & 3 & $\begin{array}{l}\text { Bank of England, East Indies Stock, \& } \\
\text { South Sea Stock }\end{array}$ & Equal Weighted & 0.03 & 3.88 \\
\hline 02/1811-12/1850 & $\begin{array}{l}\text { Rostow's Total Index } \\
\text { (Gayer, Rostow and } \\
\text { Schwartz (1975 )) }\end{array}$ & 63 & $\begin{array}{l}\text { Canals, Docks, Waterworks, Insurance, } \\
\text { Gas-light and Coke, Mines, Railways, \& } \\
\text { Banks }\end{array}$ & Value Weighted & -0.05 & 4.19 \\
\hline $01 / 1851-06 / 1867$ & $\begin{array}{l}\text { Hayek's Index (Gayer, } \\
\text { Rostow and Schwartz } \\
(1975) \text { ) }\end{array}$ & Unknown & $\begin{array}{l}\text { Canals, Docks, Waterworks, Gas-light } \\
\text { and Coke, British Mines, Railways, \& } \\
\text { miscellaneous companies }\end{array}$ & Equal Weighted & 0.13 & 1.94 \\
\hline 07/1867-12/1906 & $\begin{array}{l}\text { London and } \\
\text { Cambridge Economic } \\
\text { Service Index }\end{array}$ & $25-75$ & $\begin{array}{l}\text { Broad-based, but does not include Bank, } \\
\text { Discount Companies, Insurance \& } \\
\text { Railways }\end{array}$ & Equal Weighted & 0.10 & 1.52 \\
\hline 01/1907-05/1933 & Banker's Magazine & 287 & $\begin{array}{l}\text { Broad-based, virtually all stocks quoted } \\
\text { on the exchange }\end{array}$ & Value Weighted & -0.13 & 2.51 \\
\hline 06/1933-03/1962 & $\begin{array}{l}\text { Actuaries General } \\
\text { Index }\end{array}$ & $\begin{array}{l}30 \\
\text { industrials }\end{array}$ & $\begin{array}{l}\text { Blue-Chip index represents several } \\
\text { industries, including Financial Stocks, } \\
\text { Commodities \& Utilities, but excluded } \\
\text { Debentures \& Preferred Shares }\end{array}$ & Value Weighted & 0.40 & 3.98 \\
\hline 04/1962-11/2009 & $\begin{array}{l}\text { Financial Times- } \\
\text { Actuaries All-Share } \\
\text { Index }\end{array}$ & $\begin{array}{l}500 \\
\text { industrial } \\
\text { companies }\end{array}$ & $\begin{array}{l}\text { Broad-based, represents } 98-99 \% \text { of } \\
\text { capital value of all UK companies }\end{array}$ & Value Weighted & 0.58 & 5.48 \\
\hline
\end{tabular}


Table 2. Descriptive statistics of calendar month returns, annual returns, t-bills rates

\begin{tabular}{|c|c|c|c|c|c|c|c|c|c|c|c|c|}
\hline \multirow{2}{*}{$\begin{array}{l}\text { Sample } \\
\text { Periods }\end{array}$} & \multicolumn{2}{|c|}{ January } & \multicolumn{2}{|c|}{ February } & \multicolumn{2}{|c|}{ March } & \multicolumn{2}{|c|}{ April } & \multicolumn{2}{|c|}{ May } & \multicolumn{2}{|c|}{ June } \\
\hline & Mean & Std. Dev & Mean & Std. Dev. & Mean & Std. Dev. & Mean & Std. Dev. & Mean & Std. Dev & Mean & Std. Dev. \\
\hline 1693-2009 & 0.68 & 5.10 & 0.09 & 3.21 & -0.03 & 3.73 & 0.49 & 3.39 & 0.02 & 4.11 & -0.12 & 3.78 \\
\hline \multicolumn{13}{|c|}{ 100-year Interval } \\
\hline $1693-1800$ & -0.60 & 3.74 & 0.20 & 3.04 & 0.11 & 4.46 & 0.31 & 3.01 & 0.48 & 5.41 & 0.31 & 4.58 \\
\hline $1801-1900$ & 1.34 & 5.79 & -0.05 & 2.47 & -0.33 & 2.14 & -0.40 & 2.65 & -0.22 & 2.59 & 0.20 & 2.05 \\
\hline 1901-2009 & 1.33 & 5.37 & 0.10 & 3.92 & 0.11 & 4.07 & 1.50 & 4.05 & -0.21 & 3.74 & -0.85 & 4.05 \\
\hline \multicolumn{13}{|c|}{ 50-year Interval } \\
\hline $1693-1750$ & -0.48 & 4.72 & 0.10 & 3.71 & -0.28 & 5.72 & 0.61 & 3.70 & 1.09 & 7.11 & 0.61 & 6.00 \\
\hline $1751-1800$ & -0.73 & 2.18 & 0.32 & 2.05 & 0.56 & 2.24 & -0.04 & 1.92 & -0.23 & 2.02 & -0.04 & 1.90 \\
\hline $1801-1850$ & 1.55 & 7.98 & -0.25 & 3.03 & -0.50 & 2.53 & -0.60 & 3.48 & -0.25 & 3.30 & 0.47 & 2.36 \\
\hline $1851-1900$ & 1.13 & 2.01 & 0.14 & 1.75 & -0.16 & 1.68 & -0.21 & 1.42 & -0.19 & 1.64 & -0.07 & 1.65 \\
\hline $1901-1950$ & 0.83 & 1.41 & -0.50 & 2.32 & -0.49 & 2.50 & 0.11 & 2.79 & 0.12 & 2.76 & -0.94 & 3.68 \\
\hline 1951-2009 & 1.75 & 7.19 & 0.60 & 4.85 & 0.62 & 5.00 & 2.67 & 4.57 & -0.49 & 4.40 & -0.77 & 4.37 \\
\hline
\end{tabular}

\begin{tabular}{|c|c|c|c|c|c|c|c|c|c|c|c|c|}
\hline \multirow{2}{*}{$\begin{array}{l}\text { Sample } \\
\text { Periods }\end{array}$} & \multicolumn{2}{|c|}{ July } & \multicolumn{2}{|c|}{ August } & \multicolumn{2}{|c|}{ September } & \multicolumn{2}{|c|}{ October } & \multicolumn{2}{|c|}{ November } & \multicolumn{2}{|c|}{ December } \\
\hline & Mean & Std. Dev. & Mean & Std. Dev. & Mean & Std. Dev. & Mean & Std. Dev. & Mean & Std. Dev. & Mean & Std. Dev. \\
\hline 1693-2009 & -0.31 & 3.31 & 0.45 & 3.25 & -0.49 & 5.63 & -0.51 & 4.38 & 0.35 & 3.87 & 0.80 & 3.23 \\
\hline \multicolumn{13}{|c|}{ 100-year Interval } \\
\hline $1693-1800$ & -0.45 & 3.04 & 0.73 & 2.77 & -0.93 & 8.15 & -1.38 & 4.99 & 0.17 & 3.48 & 0.61 & 2.51 \\
\hline $1801-1900$ & -0.49 & 1.90 & -0.32 & 1.94 & -0.27 & 2.19 & -0.12 & 2.37 & 0.36 & 3.70 & 1.00 & 3.56 \\
\hline 1901-2009 & 0.00 & 4.41 & 0.89 & 4.37 & -0.26 & 4.70 & 0.02 & 5.01 & 0.51 & 4.37 & 0.80 & 3.55 \\
\hline \multicolumn{13}{|c|}{ 50-year Interval } \\
\hline $1693-1750$ & -0.34 & 3.71 & 0.71 & 3.05 & -1.81 & 10.95 & -1.95 & 6.56 & 0.45 & 3.78 & 0.80 & 2.97 \\
\hline $1751-1800$ & -0.57 & 2.03 & 0.74 & 2.42 & 0.08 & 1.95 & -0.73 & 1.87 & -0.16 & 3.10 & 0.39 & 1.83 \\
\hline $1801-1850$ & -0.94 & 2.11 & -0.78 & 2.48 & -0.86 & 2.64 & -0.28 & 2.81 & 0.55 & 4.88 & 1.67 & 4.55 \\
\hline $1851-1900$ & -0.05 & 1.55 & 0.14 & 1.02 & 0.32 & 1.44 & 0.04 & 1.83 & 0.17 & 1.96 & 0.33 & 2.01 \\
\hline $1901-1950$ & -0.18 & 4.55 & 0.49 & 3.27 & 0.41 & 2.53 & -0.03 & 3.11 & 0.84 & 3.30 & -0.44 & 2.46 \\
\hline 1951-2009 & 0.16 & 4.32 & 1.21 & 5.11 & -0.82 & 5.90 & 0.06 & 6.19 & 0.24 & 5.11 & 1.85 & 3.99 \\
\hline
\end{tabular}

\begin{tabular}{|c|c|c|c|c|c|c|}
\hline \multirow{2}{*}{$\begin{array}{l}\text { Sample } \\
\text { Periods }\end{array}$} & \multicolumn{2}{|c|}{ Annual } & \multicolumn{2}{|c|}{ T-bills Rate } & \multicolumn{2}{|c|}{ Seasonality Test } \\
\hline & Mean & Std. Dev & Mean & Std. Dev. & K-W & F-stat. \\
\hline $1693-2009$ & 0.12 & 4.00 & 0.36 & 0.18 & $55.07^{* * *}$ & $3.84^{* * *}$ \\
\hline \multicolumn{7}{|c|}{ 100-year Interval } \\
\hline $1693-1800$ & -0.04 & 4.40 & 0.35 & 0.06 & $59.75^{* * *}$ & $3.06^{* * *}$ \\
\hline $1801-1900$ & 0.06 & 3.02 & 0.33 & 0.10 & $41.21^{* * *}$ & $1.84^{* *}$ \\
\hline 1901-2009 & 0.33 & 4.36 & 0.39 & 0.29 & $35.20^{* * *}$ & $2.76^{* * *}$ \\
\hline \multicolumn{7}{|c|}{ 50-year Interval } \\
\hline $1693-1750$ & -0.04 & 5.65 & 0.33 & 0.06 & $36.06^{* * *}$ & 1.42 \\
\hline $1751-1800$ & -0.03 & 2.18 & 0.37 & 0.04 & $50.59^{* * *}$ & $3.87^{* * *}$ \\
\hline $1801-1850$ & -0.02 & 3.91 & 0.37 & 0.06 & $36.90^{* * *}$ & $2.34^{* * *}$ \\
\hline $1851-1900$ & 0.13 & 1.71 & 0.29 & 0.12 & $23.81^{* * *}$ & $1.93^{* *}$ \\
\hline $1901-1950$ & 0.02 & 3.01 & 0.21 & 0.13 & $31.31^{* * *}$ & $2.88^{* * *}$ \\
\hline $1951-2009$ & 0.59 & 5.23 & 0.55 & 0.27 & $30.09^{* * *}$ & $2.90^{* * * *}$ \\
\hline
\end{tabular}

Table 2 reports average return and standard deviation for each calendar month, entire year, and t-bills rate as a percentage. The sample is subdivided into three sub-periods of around 100-year intervals and six sub-periods of 50-year intervals. Seasonality is tested using a Kruskal and Wallis (K-W test) rank-based non-parametric equality test and parametric joint significance test. The F-stat reports the joint significance of the regression parameter $\alpha_{2}$ to $\alpha_{12}$ from the regression $R_{t}=\alpha_{1}+\alpha_{2} D_{2 t}+\alpha_{3} D_{3 t}+\cdots+\alpha_{12} D_{12 t}+\varepsilon_{t}$, where $\alpha_{1}$ is the average return of January, $\alpha_{2}$ to $\alpha_{12}$ represent the differences between January returns and the returns of the other months. ${ }^{* * *}$ denotes significance at the $1 \%$ level; ${ }^{* *}$ denotes significance at $5 \%$ level; ${ }^{*}$ denotes significance at $10 \%$ level 
Table 3. Calendar month effects

\begin{tabular}{|c|c|c|c|c|c|c|c|c|c|c|c|c|}
\hline \multirow[b]{2}{*}{ Sample Periods } & \multicolumn{2}{|c|}{ January } & \multicolumn{2}{|c|}{ February } & \multicolumn{2}{|c|}{ March } & \multicolumn{2}{|c|}{ April } & \multicolumn{2}{|c|}{ May } & \multicolumn{2}{|c|}{ June } \\
\hline & $\beta$ & t-value & $\beta$ & t-value & $\beta$ & t-value & $\beta$ & t-value & $\beta$ & t-value & $\beta$ & t-value \\
\hline 1693-2009 & 0.61 & $2.11^{* *}$ & -0.03 & -0.19 & -0.16 & -0.78 & 0.41 & $2.01^{* *}$ & -0.11 & -0.45 & -0.26 & -1.16 \\
\hline \multicolumn{13}{|l|}{ 100-year Interval } \\
\hline $1693-1800$ & -0.61 & -1.61 & 0.26 & 0.88 & 0.16 & 0.40 & 0.38 & 1.23 & 0.56 & 1.08 & 0.38 & 0.81 \\
\hline $1801-1900$ & 1.40 & $2.46^{* *}$ & -0.12 & -0.46 & -0.42 & $-1.93^{*}$ & -0.5 & $-1.69^{*}$ & -0.31 & -1.11 & 0.16 & 0.65 \\
\hline 1901-2009 & 1.09 & $2.09^{* *}$ & -0.25 & -0.65 & -0.24 & -0.59 & 1.28 & $3.13^{* * *}$ & -0.59 & -1.60 & -1.28 & $-3.23^{* * *}$ \\
\hline \multicolumn{13}{|l|}{ 50-year Interval } \\
\hline $1693-1750$ & -0.48 & -0.73 & 0.15 & 0.31 & -0.26 & -0.38 & 0.71 & 1.38 & 1.23 & 1.34 & 0.71 & 0.85 \\
\hline $1751-1800$ & -0.76 & $-2.44^{* *}$ & 0.39 & 1.30 & 0.65 & $1.91^{*}$ & -0.01 & -0.03 & -0.21 & -0.70 & -0.01 & -0.03 \\
\hline $1801-1850$ & 1.72 & 1.56 & -0.25 & -0.54 & -0.53 & -1.39 & -0.63 & -1.14 & -0.26 & -0.51 & 0.53 & 1.28 \\
\hline 1851-1900 & 1.08 & $3.88^{* * *}$ & 0.01 & 0.05 & -0.32 & -1.37 & -0.37 & -1.87 & -0.36 & -1.57 & -0.22 & -0.93 \\
\hline 1901-1950 & 0.88 & $3.69^{* * *}$ & -0.56 & -1.54 & -0.56 & -1.45 & 0.10 & 0.25 & 0.11 & 0.29 & -1.04 & $-2.01^{* *}$ \\
\hline 1951-2009 & 1.27 & 1.35 & 0.01 & 0.02 & 0.04 & 0.04 & 2.28 & $3.57^{* * *}$ & -1.18 & $-1.98^{* *}$ & -1.48 & $-2.51^{* *}$ \\
\hline
\end{tabular}

\begin{tabular}{|c|c|c|c|c|c|c|c|c|c|c|c|c|}
\hline \multirow[b]{2}{*}{ Sample Periods } & \multicolumn{2}{|c|}{ July } & \multicolumn{2}{|c|}{ August } & \multicolumn{2}{|c|}{ September } & \multicolumn{2}{|c|}{ October } & \multicolumn{2}{|c|}{ November } & \multicolumn{2}{|c|}{ December } \\
\hline & $\beta$ & t-value & $\beta$ & t-value & $\beta$ & t-value & $\beta$ & t-value & $\beta$ & t-value & $\beta$ & t-value \\
\hline 1693-2009 & -0.46 & $-2.34^{* *}$ & 0.36 & $1.94^{*}$ & -0.67 & $-2.05^{* *}$ & -0.68 & $-2.71^{* * *}$ & 0.25 & 1.13 & 0.74 & $4.00^{* * *}$ \\
\hline $\begin{array}{c}\text { 100-year Interval } \\
1693-1800\end{array}$ & -0.45 & -1.36 & 0.83 & $2.95^{* * *}$ & -0.98 & -1.22 & -1.47 & $-3.11^{* * *}$ & 0.23 & 0.61 & 0.71 & $2.52^{* *}$ \\
\hline $1801-1900$ & -0.60 & $-2.77^{* * *}$ & -0.42 & $-2.06^{* *}$ & -0.35 & -1.58 & -0.19 & -0.82 & 0.33 & 1.00 & 1.03 & $3.19^{* * *}$ \\
\hline 1901-2009 & -0.35 & -0.82 & 0.61 & 1.44 & -0.64 & -1.37 & -0.34 & -0.67 & 0.20 & 0.45 & 0.52 & 1.42 \\
\hline $\begin{array}{c}\text { 50-year Interval } \\
1693-1750\end{array}$ & -0.33 & -0.58 & 0.82 & 1.83 & -1.93 & -1.33 & -2.08 & $-2.48^{* *}$ & 0.53 & 0.93 & 0.92 & $1.90^{*}$ \\
\hline $1751-1800$ & -0.59 & $-2.08^{* *}$ & 0.84 & $2.59^{* * *}$ & 0.12 & 0.45 & -0.76 & $-2.84^{* * *}$ & -0.13 & -0.30 & 0.46 & $1.89^{*}$ \\
\hline $1801-1850$ & -1.00 & $-2.83^{* * *}$ & -0.83 & $-2.25^{* *}$ & -0.92 & $-2.36^{* *}$ & -0.29 & -0.69 & 0.62 & 1.04 & 1.84 & $3.29^{* * *}$ \\
\hline $1851-1900$ & -0.20 & -0.83 & 0.00 & 0.02 & 0.21 & 0.98 & -0.10 & -0.41 & 0.04 & 0.15 & 0.21 & 0.74 \\
\hline 1901-1950 & -0.22 & -0.33 & 0.52 & 1.10 & 0.43 & 1.13 & -0.05 & -0.12 & 0.90 & 1.85 & -0.49 & -1.35 \\
\hline 1951-2009 & -0.47 & -0.82 & 0.68 & 1.01 & -1.54 & $-1.96^{* *}$ & -0.58 & -0.69 & -0.38 & -0.54 & 1.37 & $2.42^{* *}$ \\
\hline
\end{tabular}

Table 3 presents the coefficients (percentage) and the t-statistics of the regression in a form of $R_{t}=\alpha+\beta_{m} D_{m t}+\varepsilon_{t}$, where $R_{t}$ is the continuously compounded monthly returns, $D_{m t}$ is the dummy variable of the calendar month $\mathrm{m}, \alpha$ is the constant, and $\varepsilon_{t}$ is the error term. T-statistics are calculated based on Newey-West standard errors. The sample is sub-divided into three sub-periods of approximately 100-year intervals and six sub-periods of 50-year intervals. $^{* * *}$ denotes significance at the $1 \%$ level; ${ }^{* *}$ denotes significance at $5 \%$ level; ${ }^{*}$ denotes significance at $10 \%$ level 
Table 4. January effect before and after Christmas becomes a national holiday

\begin{tabular}{|c|c|c|c|c|c|c|c|c|}
\hline \multirow[t]{2}{*}{ Country } & \multirow[t]{2}{*}{ Breakpoint } & \multirow[t]{2}{*}{ Sample periods } & \multicolumn{2}{|c|}{$\begin{array}{c}\text { January Effect } \\
\text { before breakpoint }\end{array}$} & \multicolumn{2}{|c|}{$\begin{array}{c}\text { January Effect } \\
\text { after breakpoint }\end{array}$} & \multicolumn{2}{|c|}{ Difference } \\
\hline & & & $\beta_{\mathrm{b}}$ & t-value & $\beta_{a}$ & t-value & $\boldsymbol{\beta}_{\mathrm{b}}-\boldsymbol{\beta}_{\mathrm{a}}$ & t-value \\
\hline \multirow[t]{3}{*}{ UK } & 1837 & $1787-1887$ & 0.67 & 0.61 & 1.43 & $4.29^{* * *}$ & -0.76 & -0.65 \\
\hline & & $1737-1937$ & 0.03 & 0.06 & 1.30 & $6.71^{* * *}$ & -1.26 & $-2.07^{* * *}$ \\
\hline & & 1693-2009 & -0.22 & -0.47 & 1.30 & $3.81^{* * *}$ & -1.53 & $-2.62^{* * *}$ \\
\hline \multirow[t]{3}{*}{ US } & 1870 & $1820-1920$ & -0.89 & -1.57 & 1.06 & $2.78^{* * *}$ & -0.19 & $-2.91^{* * *}$ \\
\hline & & $1791-1970$ & -0.80 & $-1.93^{*}$ & 0.94 & $2.63^{* * *}$ & -1.74 & $-3.26^{* * *}$ \\
\hline & & 1791-2009 & -0.86 & $-2.08^{* * *}$ & 0.91 & $2.67^{* * *}$ & -1.77 & $-3.37^{* * *}$ \\
\hline
\end{tabular}

Table 4 shows the coefficient estimates in percentage terms and the t-statistics of the regression $R_{t}=\alpha+\beta_{b} J a n_{t}(1-$ Christmas $\left._{t}\right)+\beta_{a}$ Jan $_{t}$ Christmas $_{t}+\varepsilon_{t}$ where $R_{t}$ is the continuously compounded monthly index returns, Jan ${ }_{t}$ is the January dummy, Christmas t $_{t}$ is the Christmas holiday dummy that equals one for the period after the introduction of Christmas holiday and zero otherwise. $\alpha$ is the constant and $\varepsilon_{t}$ is the error term. $\beta_{b}$ shows the January effect before Christmas becomes a holiday and $\left(\beta_{a}\right)$ afterwards. The last two columns examine the significance of the difference in the January effect before and after the breakpoint. T-statistics are calculated based on Newey-West standard errors. ${ }^{* * *}$ denotes significance at the $1 \%$ level; ${ }^{* *}$ denotes significance at $5 \%$ level; ${ }^{*}$ denotes significance at $10 \%$ level 
Table 5. Halloween effect

\begin{tabular}{|c|c|c|c|c|c|c|c|c|}
\hline \multirow[b]{2}{*}{$\begin{array}{l}\text { Sample } \\
\text { Periods }\end{array}$} & \multicolumn{3}{|c|}{ Winter } & \multicolumn{3}{|c|}{ Summer } & \multicolumn{2}{|c|}{ Halloween } \\
\hline & Mean & $\begin{array}{l}\text { Standard } \\
\text { Deviation }\end{array}$ & $\begin{array}{c}\text { Percentage } \\
\text { of Positive } \\
\text { Returns } \\
\end{array}$ & Mean & $\begin{array}{l}\text { Standard } \\
\text { Deviation }\end{array}$ & $\begin{array}{c}\text { Percentage } \\
\text { of Positive } \\
\text { Returns } \\
\end{array}$ & $\beta$ & t-value \\
\hline 1693-2009 & 0.40 & 3.82 & 0.61 & -0.16 & 4.16 & 0.49 & 0.56 & $4.26^{* * *}$ \\
\hline $\begin{array}{l}\text { 100-year } \\
\text { Interval }\end{array}$ & & & & & & & & \\
\hline $1693-1800$ & 0.13 & 3.44 & 0.57 & -0.21 & 5.18 & 0.46 & 0.34 & 1.6 \\
\hline $1801-1900$ & 0.32 & 3.64 & 0.60 & -0.20 & 2.19 & 0.47 & 0.52 & $2.71^{* * *}$ \\
\hline 1901-2009 & 0.72 & 4.28 & 0.66 & -0.07 & 4.41 & 0.52 & 0.80 & $3.03^{* * *}$ \\
\hline $\begin{array}{l}\text { 50-year } \\
\text { Interval }\end{array}$ & & & & & & & & \\
\hline $1693-1750$ & 0.20 & 4.19 & 0.59 & -0.28 & 6.80 & 0.48 & 0.48 & 1.29 \\
\hline $1751-1800$ & 0.06 & 2.28 & 0.56 & -0.13 & 2.08 & 0.44 & 0.18 & 0.93 \\
\hline $1801-1850$ & 0.40 & 4.81 & 0.62 & -0.44 & 2.67 & 0.38 & 0.84 & $2.29^{* *}$ \\
\hline 1851-1900 & 0.23 & 1.86 & 0.58 & 0.03 & 1.54 & 0.56 & 0.20 & 1.46 \\
\hline 1901-1950 & 0.06 & 2.57 & 0.58 & -0.02 & 3.39 & 0.48 & 0.08 & 0.31 \\
\hline 1951-2009 & 1.29 & 5.25 & 0.73 & -0.11 & 5.12 & 0.56 & 1.40 & $3.33^{* * *}$ \\
\hline
\end{tabular}

Table 5 reports the mean returns, standard deviations, and percentage of positive returns for Winter (November to April) and Summer (May to October). The last two columns present the coefficient estimates and t-statistics for the regression of $R_{t}=\alpha+\beta D_{\text {hal }}+\varepsilon_{t}$. T-statistics are calculated based on Newey-West standard errors. The sample is sub-divided into three sub-periods of approximately 100-year intervals and six sub-periods of 50-year intervals. ${ }^{* * *}$ denotes significance at the $1 \%$ level; ${ }^{* *}$ denotes significance at $5 \%$ level; ${ }^{*}$ denotes significance at $10 \%$ level 
Table 6. Halloween effect semi-annual data versus monthly data

\begin{tabular}{|c|c|c|c|c|}
\hline \multirow{2}{*}{$\begin{array}{l}\text { Sample } \\
\text { Periods }\end{array}$} & \multicolumn{2}{|c|}{ Semi-annual data } & \multicolumn{2}{|c|}{ Monthly data } \\
\hline & $\boldsymbol{\beta}$ & t-value & $\boldsymbol{\beta}$ & t-value \\
\hline 1693-2009 & 3.36 & $4.39^{* * *}$ & 0.56 & $4.26^{* * *}$ \\
\hline \multicolumn{5}{|c|}{ 100-year Interval } \\
\hline $1693-1800$ & 2.03 & $1.71^{*}$ & 0.34 & 1.6 \\
\hline $1801-1900$ & 3.14 & $3.03^{* * *}$ & 0.52 & $2.71^{* * *}$ \\
\hline 1901-2009 & 4.87 & $3.04^{* * *}$ & 0.80 & $3.03^{* * *}$ \\
\hline \multicolumn{5}{|c|}{ 50-year Interval } \\
\hline 1693-1750 & 2.83 & 1.47 & 0.48 & 1.29 \\
\hline $1751-1800$ & 1.10 & 0.88 & 0.18 & 0.93 \\
\hline $1801-1850$ & 5.06 & $2.88^{* * *}$ & 0.84 & $2.29^{* *}$ \\
\hline $1851-1900$ & 1.22 & 1.33 & 0.20 & 1.46 \\
\hline 1901-1950 & 0.67 & 0.4 & 0.08 & 0.31 \\
\hline 1951-2009 & 8.43 & $3.59^{* * *}$ & 1.40 & $3.33^{* * *}$ \\
\hline
\end{tabular}

Table 6 compares the regression results of the Halloween effect using semiannual data and monthly data. Coefficient estimates are in percentage terms. T-statistics are calculated based on Newey-West standard errors. The sample is sub-divided into three sub-periods of approximately 100-year intervals and six sub-periods of 50-year intervals. ${ }^{* * *}$ denotes significance at the $1 \%$ level; ${ }^{* *}$ denotes significance at 5\% level; ${ }^{*}$ denotes significance at $10 \%$ level 
Table 7. Annual performance of Buy \& Hold strategy versus Halloween strategy

\begin{tabular}{|c|c|c|c|c|c|c|c|c|c|}
\hline \multirow{2}{*}{ Sample Periods- } & \multicolumn{3}{|c|}{ Buy \& Hold Strategy } & \multicolumn{3}{|c|}{ Halloween Strategy } & \multirow{2}{*}{ Obs. } & \multirow{2}{*}{$\begin{array}{c}\text { Number of } \\
\text { Winning }\end{array}$} & \multirow{2}{*}{$\begin{array}{c}\text { Percentage } \\
\text { of } \\
\text { Winning }\end{array}$} \\
\hline & Return & Std. Dev. & $\begin{array}{c}\text { Sharpe } \\
\text { ratio }\end{array}$ & Return & Std. Dev. & $\begin{array}{c}\text { Sharpe } \\
\text { ratio }\end{array}$ & & & \\
\hline $1693-2009$ & 1.38 & 14.58 & 0.09 & 4.52 & 10.71 & 0.42 & 316 & 200 & $63.29 \%$ \\
\hline \multicolumn{10}{|l|}{ 100-year interval } \\
\hline $1693-1800$ & -0.52 & 11.54 & -0.05 & 2.95 & 8.92 & 0.33 & 107 & 70 & $65.42 \%$ \\
\hline $1801-1900$ & 0.68 & 11.90 & 0.06 & 3.86 & 8.20 & 0.47 & 100 & 69 & $69.00 \%$ \\
\hline $1901-2009$ & 3.91 & 18.71 & 0.21 & 6.69 & 13.68 & 0.49 & 109 & 61 & $55.96 \%$ \\
\hline \multicolumn{10}{|l|}{ 50-year interval } \\
\hline $1693-1750$ & -0.49 & 13.16 & -0.04 & 3.19 & 10.82 & 0.29 & 57 & 32 & $56.14 \%$ \\
\hline $1751-1800$ & -0.56 & 9.45 & -0.06 & 2.66 & 6.14 & 0.43 & 50 & 38 & $76.00 \%$ \\
\hline $1801-1850$ & -0.21 & 14.81 & -0.01 & 4.62 & 10.46 & 0.44 & 50 & 38 & $76.00 \%$ \\
\hline $1851-1900$ & 1.58 & 8.07 & 0.20 & 3.10 & 5.01 & 0.62 & 50 & 31 & $62.00 \%$ \\
\hline $1901-1950$ & 0.20 & 11.07 & 0.02 & 1.59 & 6.00 & 0.26 & 50 & 28 & $56.00 \%$ \\
\hline $1950-2009$ & 7.05 & 22.95 & 0.31 & 11.01 & 16.64 & 0.66 & 59 & 33 & $55.93 \%$ \\
\hline \multicolumn{10}{|l|}{ 30-year interval } \\
\hline $1693-1730$ & -0.62 & 15.52 & -0.04 & 3.83 & 13.16 & 0.29 & 37 & 22 & $59.46 \%$ \\
\hline $1731-1760$ & -1.12 & 6.60 & -0.17 & 1.71 & 3.50 & 0.49 & 30 & 20 & $66.67 \%$ \\
\hline $1761-1790$ & 0.28 & 9.77 & 0.03 & 4.00 & 6.60 & 0.61 & 30 & 22 & $73.33 \%$ \\
\hline $1791-1820$ & -0.22 & 11.48 & -0.02 & 3.04 & 5.75 & 0.53 & 30 & 21 & $70.00 \%$ \\
\hline $1821-1850$ & -0.39 & 16.82 & -0.02 & 4.69 & 12.93 & 0.36 & 30 & 23 & $76.67 \%$ \\
\hline $1851-1880$ & 1.45 & 9.03 & 0.16 & 3.45 & 5.57 & 0.62 & 30 & 18 & $60.00 \%$ \\
\hline $1881-1910$ & 0.84 & 6.73 & 0.13 & 2.31 & 3.59 & 0.64 & 30 & 20 & $66.67 \%$ \\
\hline $1911-1940$ & -1.19 & 11.86 & -0.10 & 1.12 & 7.01 & 0.16 & 30 & 17 & $56.67 \%$ \\
\hline $1941-1970$ & 5.84 & 14.89 & 0.39 & 5.21 & 9.30 & 0.56 & 30 & 13 & $43.33 \%$ \\
\hline $1971-2009$ & 7.61 & 25.75 & 0.30 & 13.36 & 18.68 & 0.72 & 39 & 24 & $61.54 \%$ \\
\hline
\end{tabular}

Table 7 presents the average annual returns, standard deviations in percentages, and Sharpe ratios of the buy and hold strategy and the Halloween strategy, as well as the number of years, and the percentage of times that the Halloween strategy outperforms the Buy \& Hold strategy for the whole sample period from 1693-2009, three subsamples of around 100 years, six 50-year subsamples, and ten 30year subsamples 


\begin{tabular}{|c|c|c|c|c|c|c|c|c|c|c|c|c|c|}
\hline \multirow{3}{*}{$\begin{array}{l}\text { Holding } \\
\text { Horizon }\end{array}$} & \multicolumn{13}{|c|}{ Overlapping Sample } \\
\hline & \multicolumn{5}{|c|}{ Buy \& Hold Strategy } & \multicolumn{5}{|c|}{ Halloween Strategy } & \multirow[t]{2}{*}{ Obs. } & \multirow{2}{*}{$\begin{array}{l}\text { No. of } \\
\text { Win }\end{array}$} & \multirow[t]{2}{*}{$\%$ Win } \\
\hline & $\overline{\text { Return }}$ & St. Dev. & Skewness & Maximum & Minimum & $\overline{\text { Return }}$ & St. Dev. & Skewness & Maximum & Minimum & & & \\
\hline 1-Year & 1.38 & 14.58 & 0.12 & 86.01 & -80.60 & 4.52 & 10.71 & 2.06 & 83.59 & -30.96 & 317 & 200 & $63.09 \%$ \\
\hline 2-Year & 1.42 & 14.50 & -0.39 & 41.03 & -59.11 & 4.56 & 11.16 & 1.60 & 59.91 & -28.78 & 316 & 223 & $70.57 \%$ \\
\hline 3-Year & 1.50 & 14.00 & 0.10 & 38.85 & -35.39 & 4.61 & 11.09 & 1.75 & 46.05 & -11.12 & 315 & 236 & $74.92 \%$ \\
\hline 4-Year & 1.55 & 13.50 & 0.31 & 29.79 & -25.50 & 4.63 & 11.40 & 1.58 & 35.02 & -7.86 & 314 & 250 & $79.62 \%$ \\
\hline 5-Year & 1.59 & 13.12 & 0.58 & 24.68 & -16.06 & 4.64 & 11.92 & 1.59 & 33.33 & -6.28 & 313 & 257 & $82.11 \%$ \\
\hline 6-Year & 1.60 & 12.96 & 0.77 & 24.56 & -15.91 & 4.65 & 12.34 & 1.66 & 29.53 & -3.66 & 312 & 258 & $82.69 \%$ \\
\hline 7-Year & 1.60 & 12.75 & 1.01 & 22.05 & -12.75 & 4.65 & 12.76 & 1.76 & 29.35 & -4.07 & 311 & 267 & $85.85 \%$ \\
\hline 8-Year & 1.59 & 12.67 & 1.27 & 21.79 & -10.89 & 4.66 & 13.21 & 1.81 & 27.33 & -2.46 & 310 & 271 & $87.42 \%$ \\
\hline 9-Year & 1.59 & 12.78 & 1.35 & 21.67 & -7.98 & 4.66 & 13.73 & 1.87 & 27.15 & -2.83 & 309 & 281 & $90.94 \%$ \\
\hline 10-Year & 1.61 & 13.00 & 1.43 & 21.82 & -8.16 & 4.67 & 14.23 & 1.91 & 27.06 & -2.89 & 308 & 282 & $91.56 \%$ \\
\hline 15-Year & 1.63 & 13.98 & 1.56 & 19.27 & -6.52 & 4.67 & 16.27 & 2.04 & 24.81 & -0.20 & 303 & 282 & $93.07 \%$ \\
\hline \multirow[t]{4}{*}{ 20-Year } & 1.61 & 14.75 & 1.72 & 15.62 & -3.56 & 4.64 & 17.82 & 2.04 & 20.57 & 0.18 & 298 & 281 & $94.30 \%$ \\
\hline & \multicolumn{13}{|c|}{ Non-Overlapping Sample } \\
\hline & \multicolumn{5}{|c|}{ Buy \& Hold Strategy } & \multicolumn{5}{|c|}{ Halloween Strategy } & \multirow[t]{2}{*}{ Obs. } & \multirow{2}{*}{$\begin{array}{l}\text { No. of } \\
\text { Win }\end{array}$} & \multirow[t]{2}{*}{$\%$ Win } \\
\hline & Return & St. Dev. & Skewness & Maximum & Minimum & $\overline{\text { Return }}$ & St. Dev. & Skewness & Maximum & Minimum & & & \\
\hline 1-Year & - & - & - & - & - & - & - & - & - & - & - & - & - \\
\hline 2-Year & 1.33 & 16.35 & -0.59 & 41.03 & -59.11 & 4.53 & 12.50 & 1.66 & 59.91 & -28.78 & 158 & 110 & $69.62 \%$ \\
\hline 3-Year & 1.46 & 16.12 & 0.15 & 38.85 & -35.39 & 4.55 & 12.51 & 2.22 & 46.05 & -11.12 & 105 & 80 & $76.19 \%$ \\
\hline 4-Year & 1.33 & 15.87 & -0.14 & 21.70 & -25.50 & 4.53 & 11.63 & 1.01 & 23.35 & -7.86 & 79 & 60 & $75.95 \%$ \\
\hline 5-Year & 1.46 & 13.36 & -0.01 & 16.46 & -16.06 & 4.55 & 11.49 & 1.01 & 22.53 & -6.28 & 63 & 51 & $80.95 \%$ \\
\hline 6-Year & 1.37 & 16.41 & 0.72 & 24.56 & -15.91 & 4.52 & 14.23 & 2.23 & 29.53 & -3.01 & 52 & 42 & $80.77 \%$ \\
\hline 7-Year & 1.46 & 13.39 & 0.79 & 18.44 & -8.76 & 4.55 & 13.55 & 1.15 & 20.27 & -4.07 & 45 & 41 & $91.11 \%$ \\
\hline 8-Year & 1.37 & 11.73 & 1.13 & 14.43 & -6.98 & 4.52 & 12.58 & 1.64 & 20.17 & -1.70 & 39 & 36 & $92.31 \%$ \\
\hline 9-Year & 1.46 & 13.15 & 0.99 & 15.75 & -7.98 & 4.55 & 14.06 & 1.85 & 21.66 & -2.40 & 35 & 32 & $91.43 \%$ \\
\hline 10-Year & 1.30 & 11.82 & 1.19 & 12.72 & -5.45 & 4.51 & 13.80 & 1.73 & 18.57 & -1.51 & 31 & 29 & $93.55 \%$ \\
\hline 15-Year & 1.46 & 15.36 & 0.88 & 12.33 & -4.08 & 4.55 & 16.47 & 1.77 & 17.75 & 0.38 & 21 & 20 & $95.24 \%$ \\
\hline 20-Year & 1.24 & 15.36 & 1.53 & 9.16 & -2.51 & 4.36 & 18.77 & 2.39 & 17.34 & 0.18 & 15 & 14 & $93.33 \%$ \\
\hline
\end{tabular}

Table 8 shows average returns, standard deviations, skewness, and the maximum and minimum values of the buy and hold strategy and the Halloween strategy for different holding horizons from one year to twenty years. The average returns and the standard deviations are annualized by dividing the total returns (standard deviations) by $n(\sqrt{n})$. The No. of Winning and the \% of Winning are the number of times and the percentage of times that the Halloween strategy beats the Buy \& Hold strategy, respectively. The upper panel presents the results calculated using the overlapping sample, and the lower panel are the results from the nonoverlapping sample. 
Figure 1. United Kingdom: 10-year moving average of the difference between January returns and the average returns for the other 11 months

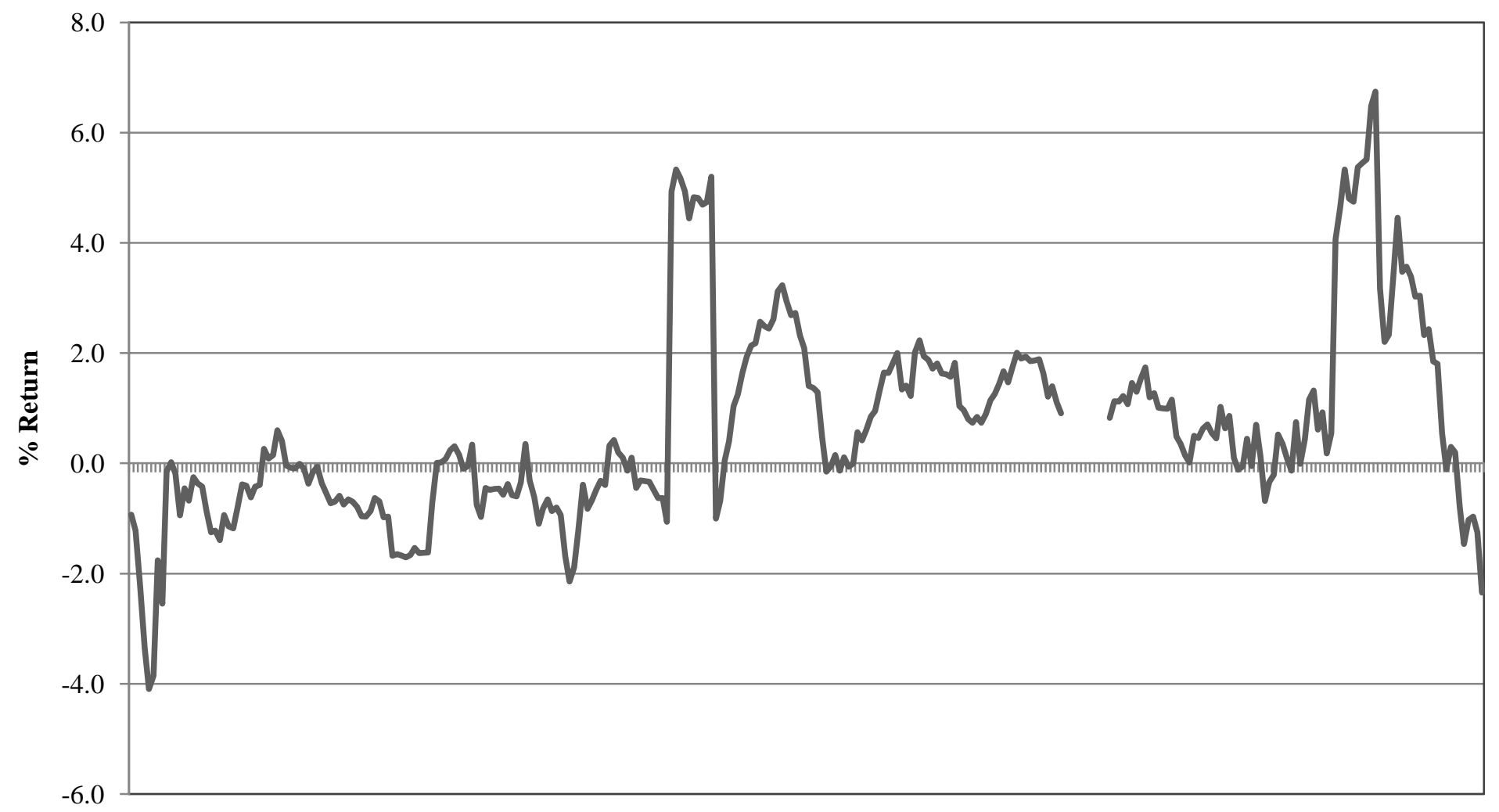

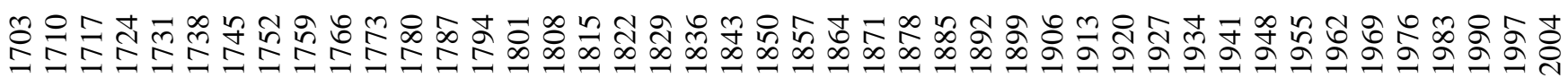
Year 
Figure 2. United States: 10-year moving average of the difference between January returns and the average returns for the other 11 months

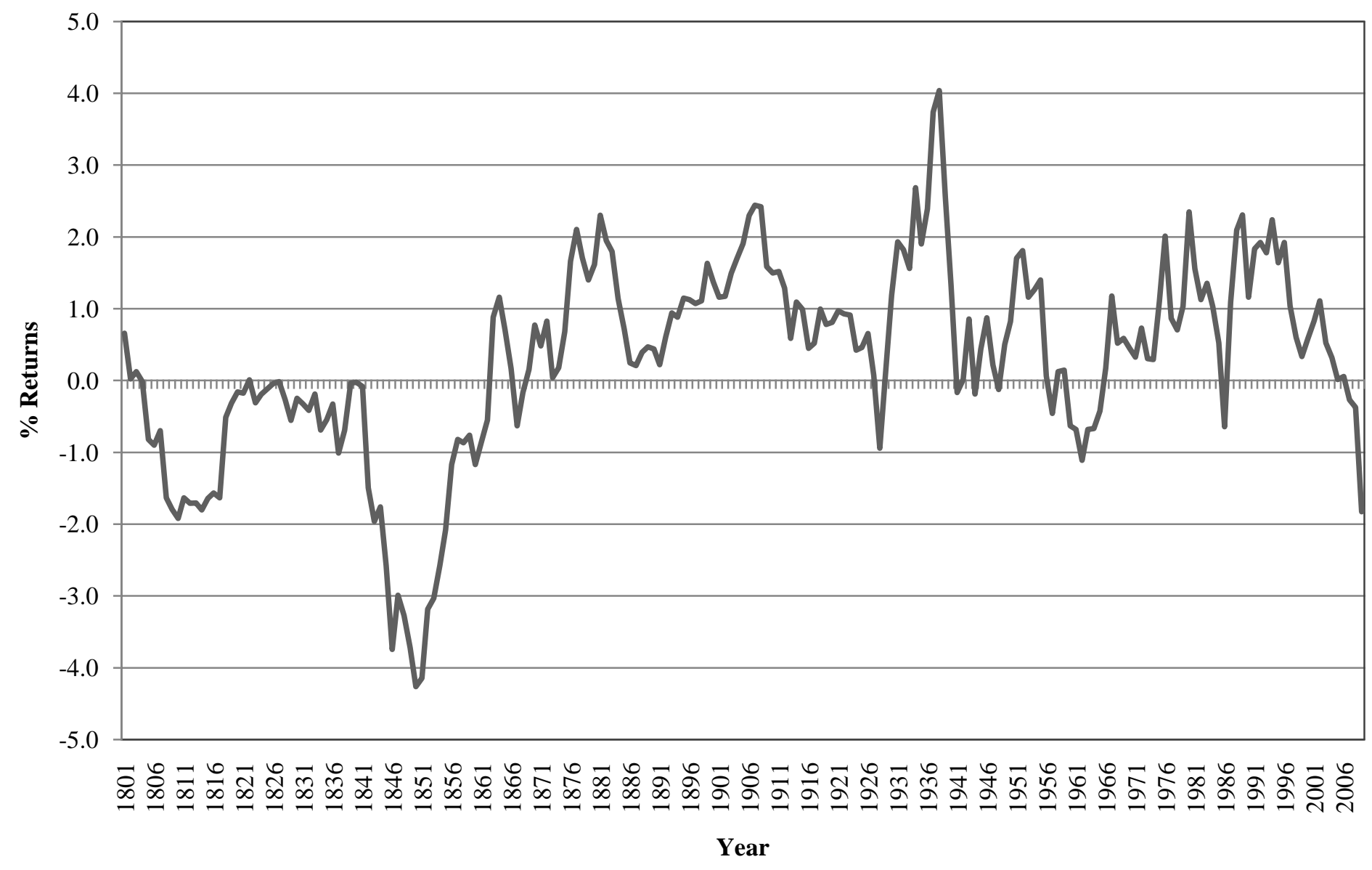


Figure 3. April return and April effect

\section{April return}

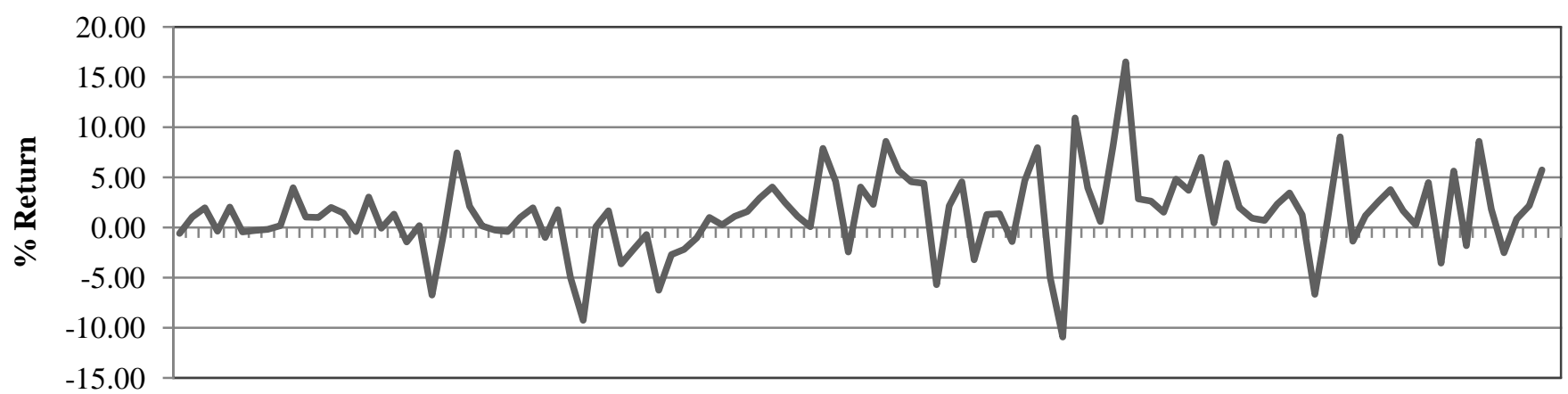

ஓ ڤ

\section{Year}

\section{Return difference between April and average of 11 months}

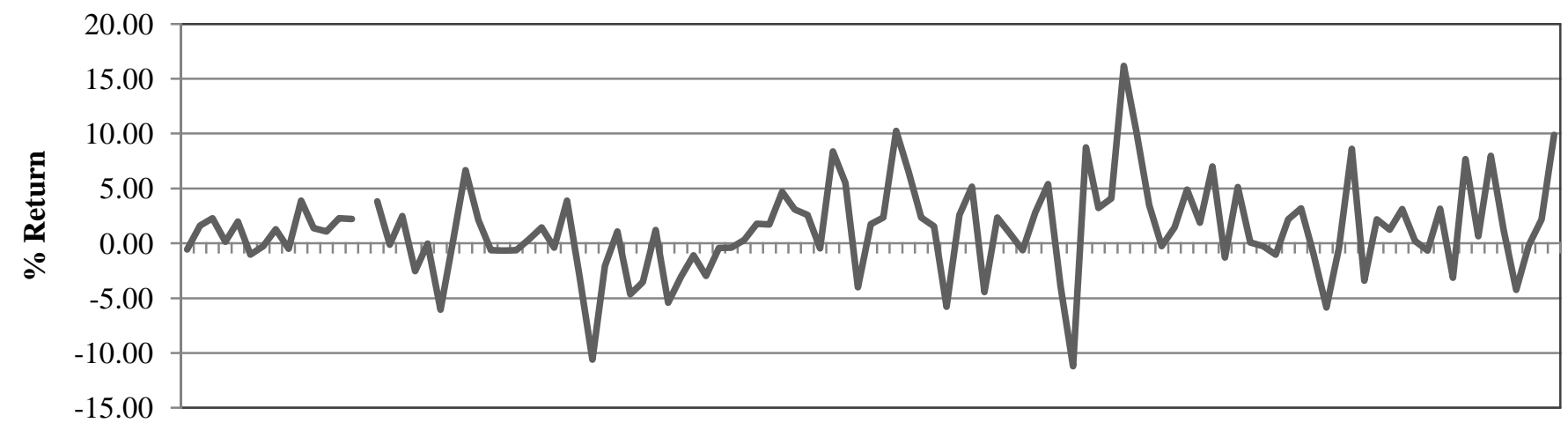

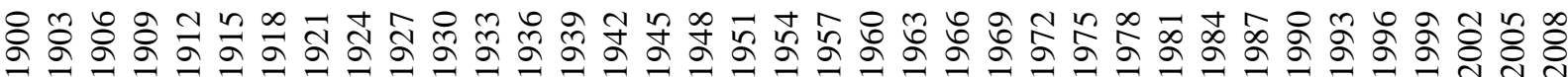
Year

\section{Return difference between April and average of 11 months (10-year moving average)}

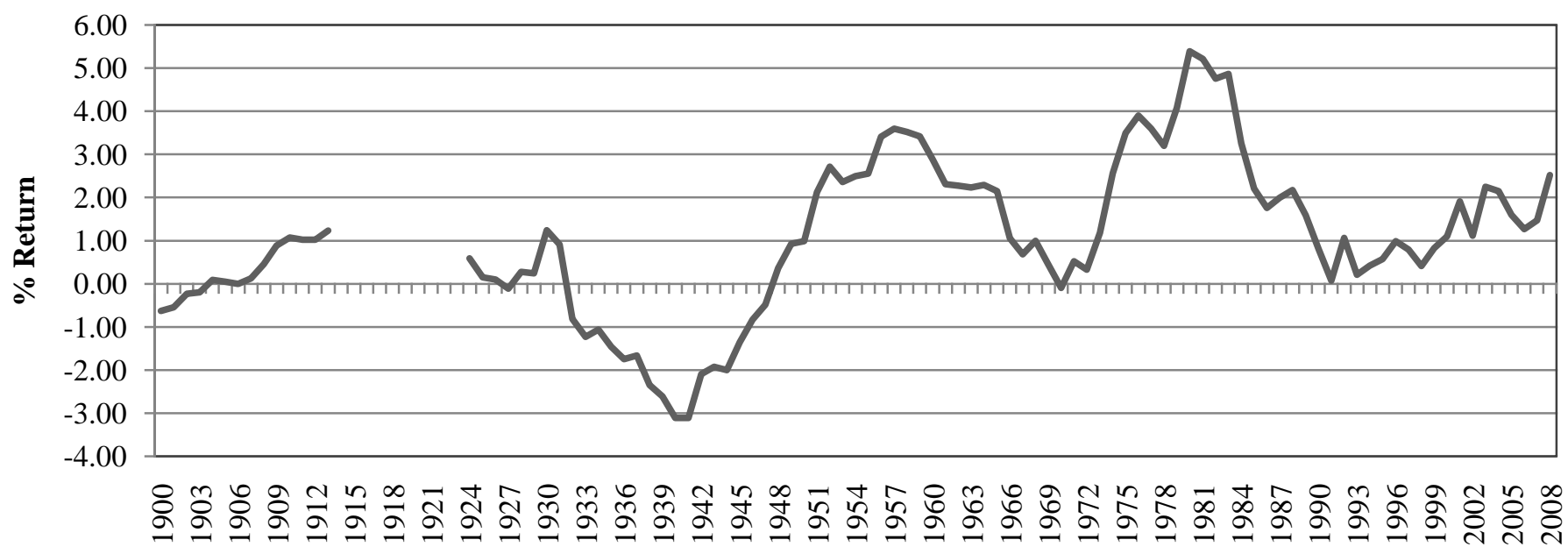

Year 


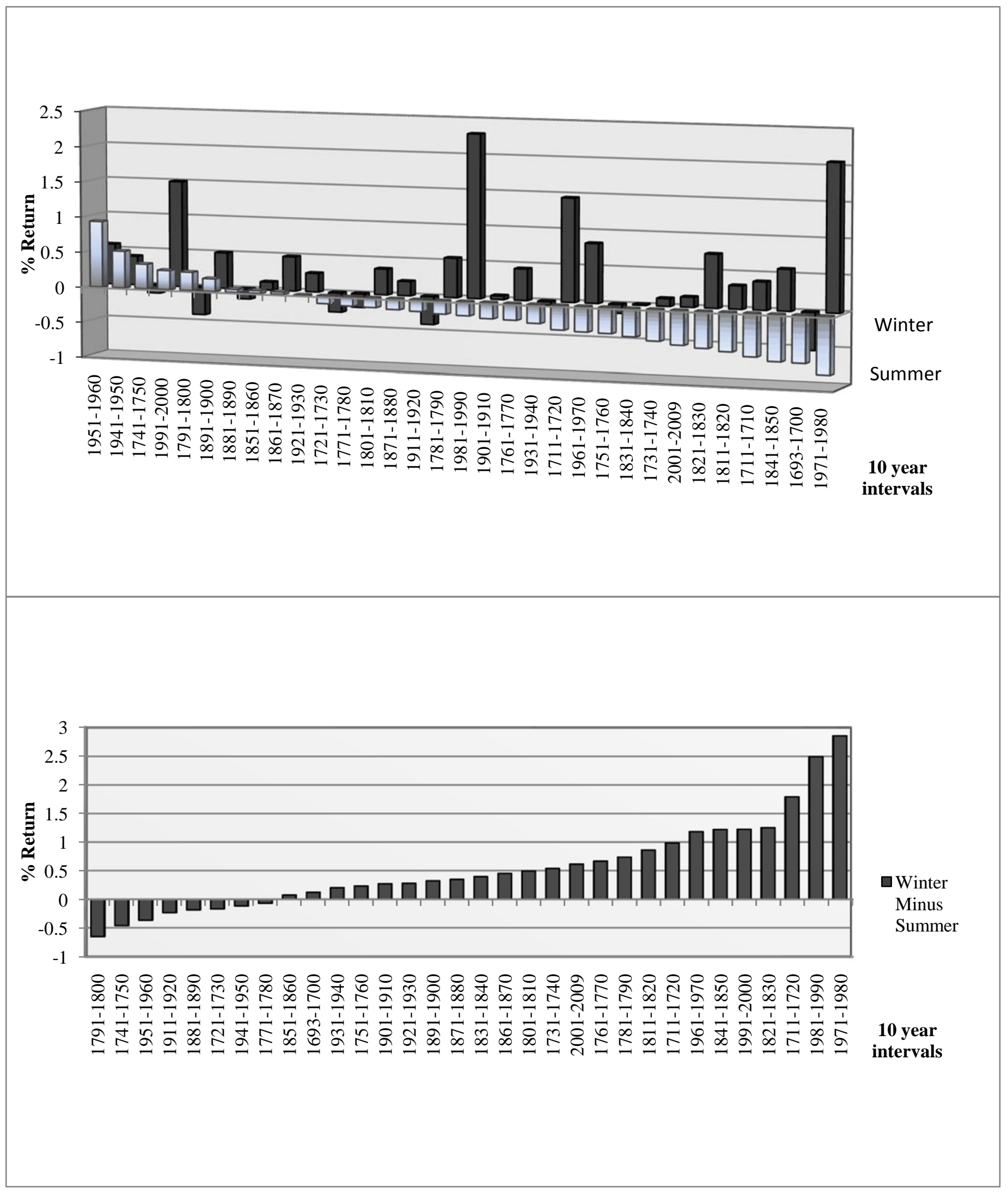

Figure 4 Upper plot shows the average winter (Nov-Apr) returns and the average summer returns (May-Oct) of 32 ten-year intervals in descending summer returns order. Lower plot shows the difference between average winter returns and the average summer returns in ascending order. 
Figure 5. 10-year moving average of summer risk premia

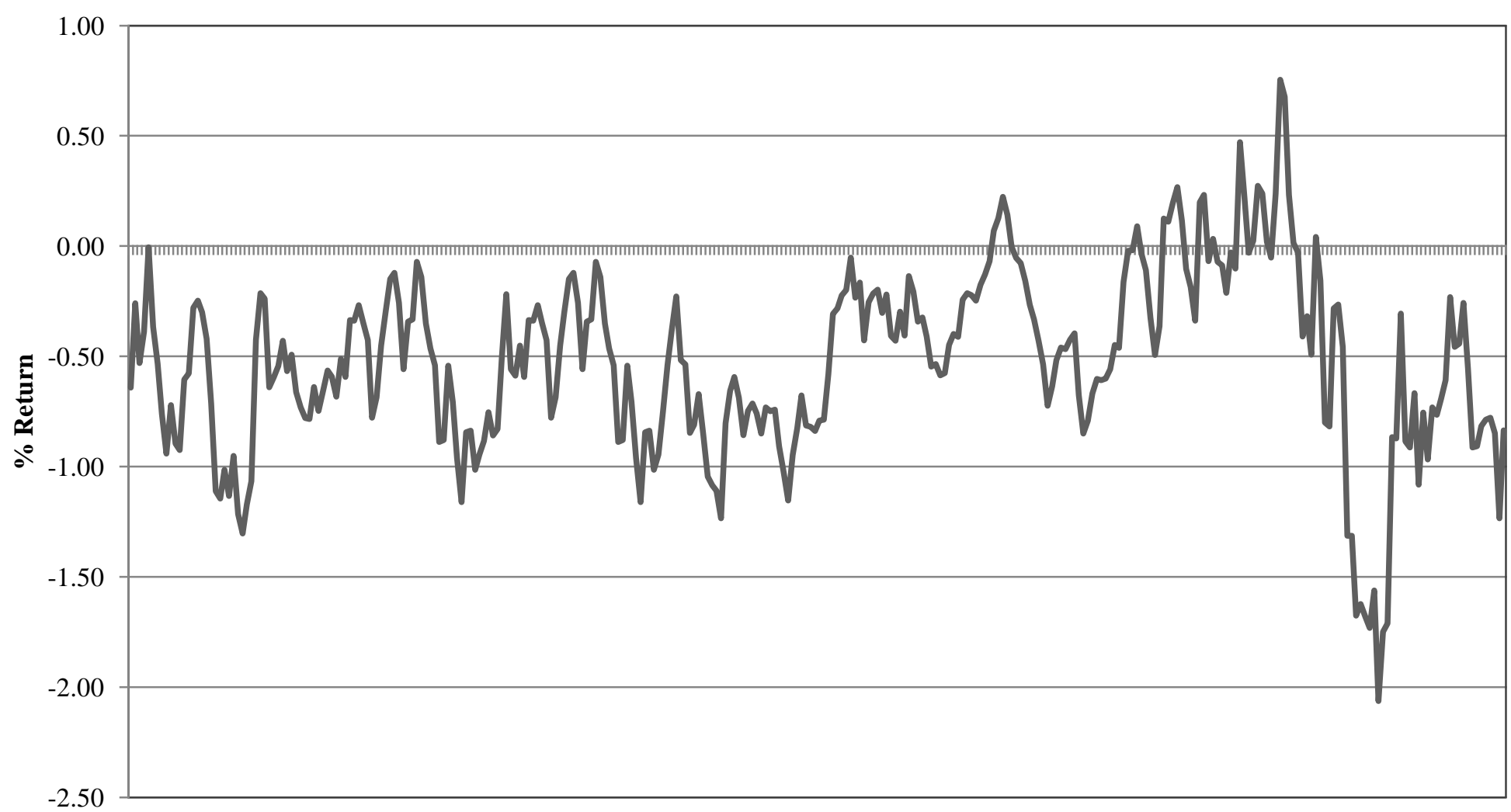

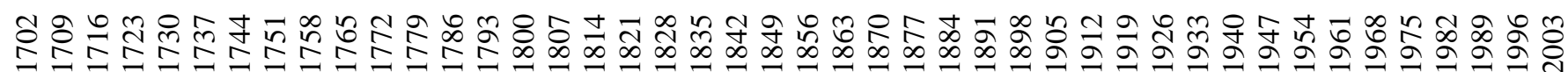
Year 
Figure 6. Return frequency distribution of Buy \& Hold strategy and Halloween strategy

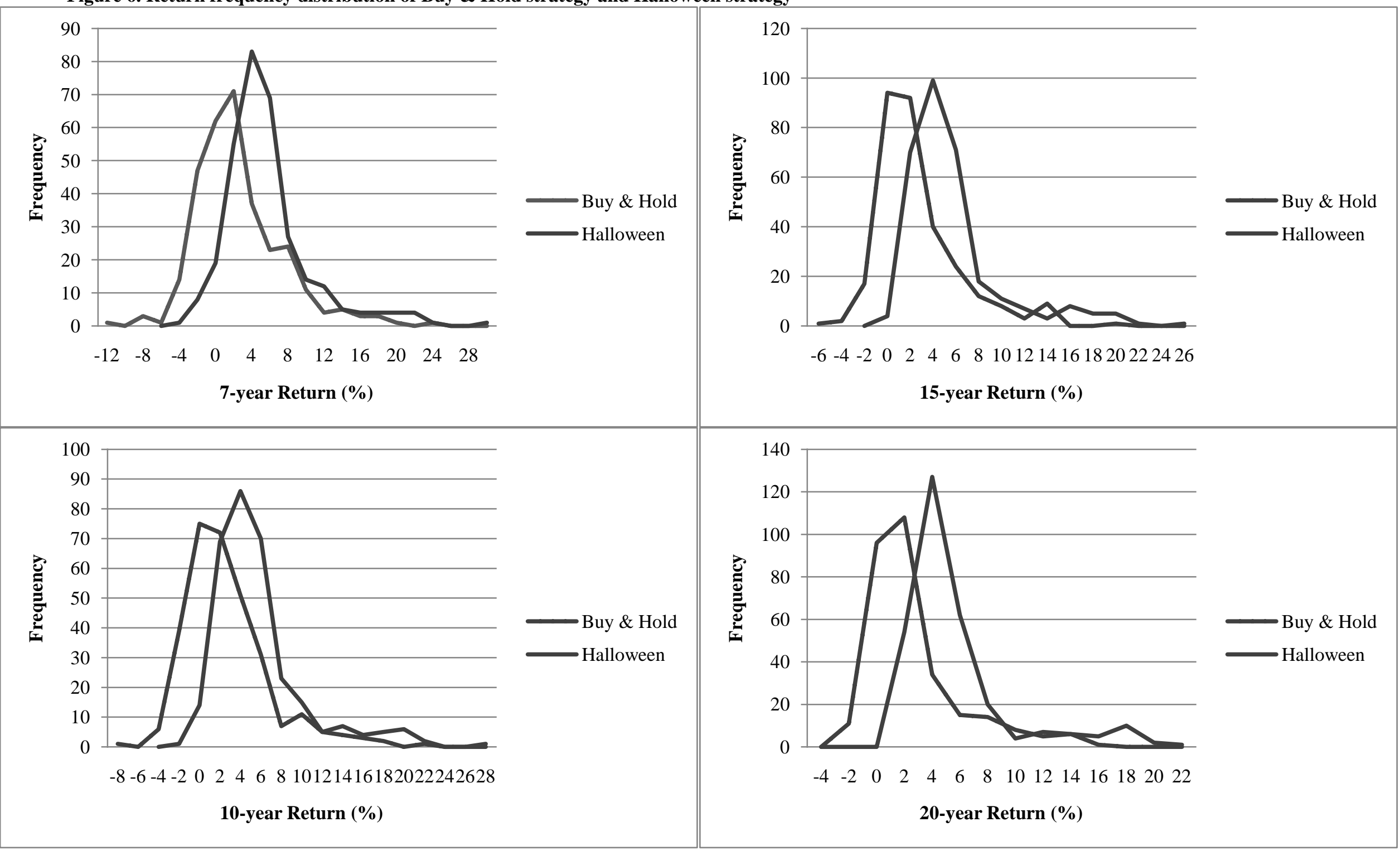

Figure 6 shows the return frequencies of the Buy \& Hold strategy and the Halloween strategy for the holding periods of seven years, ten years, fifteen years, and twenty years. The returns are annualized and expressed in percentages. 
Figure 7. End of period wealth for the buy and hold strategy and the Halloween strategy for the period 1693 to 2009

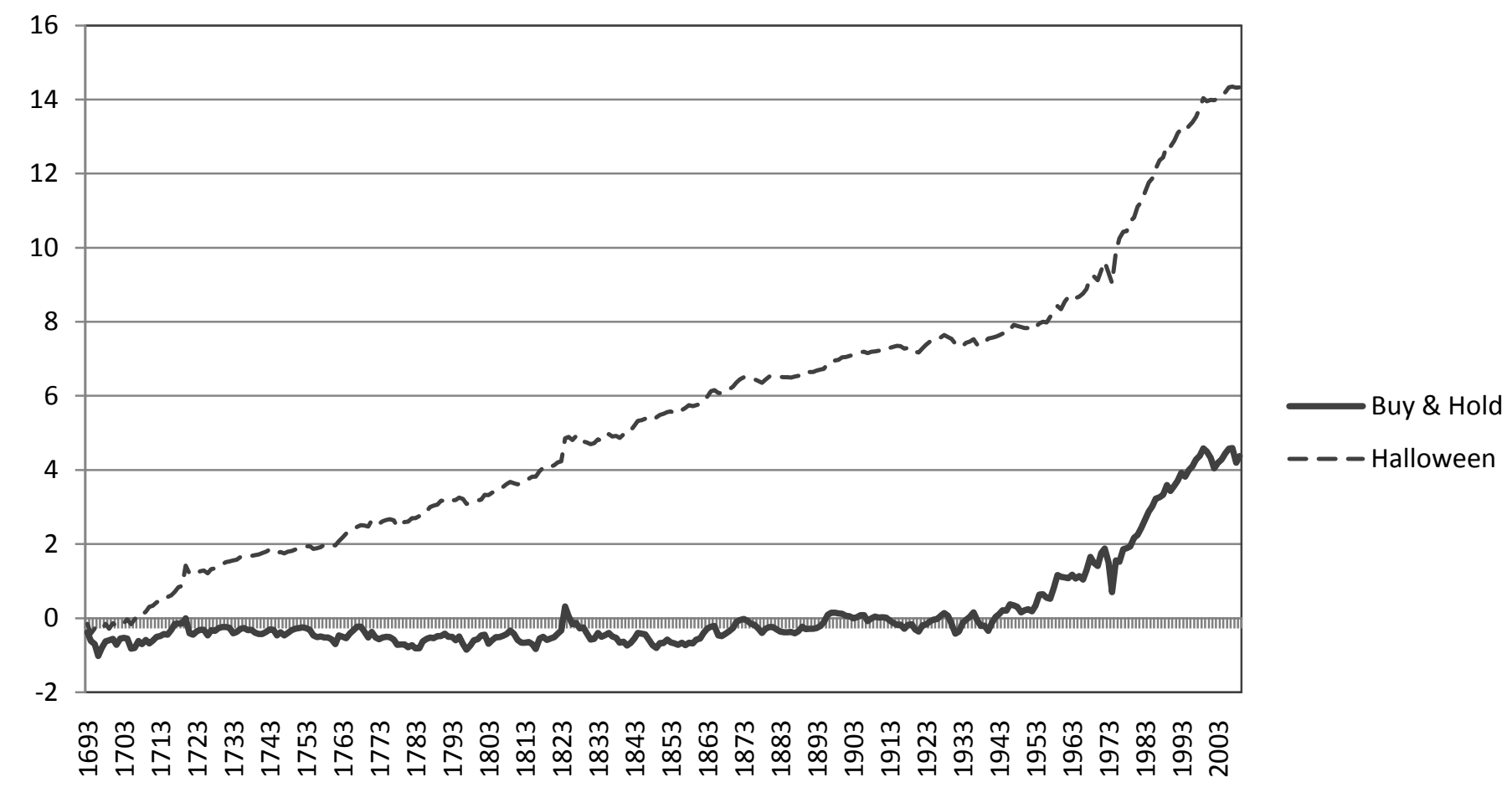

Year 